\title{
Microbiological quality, chemical profile as well as antioxidant and antidiabetic activities of Schinus terebinthifolius Raddi
}

\author{
Paola dos Santos da Rocha ${ }^{\mathrm{a}}$, Ana Paula de Araújo Boleti ${ }^{\mathrm{a}}$, Maria do Carmo Vieira ${ }^{\mathrm{b}}$, \\ Carlos Alexandre Carolloc, Denise Brentan da Silva ${ }^{\mathrm{c}}$, Leticia Miranda Estevinho ${ }^{\mathrm{d}}$, \\ Edson Lucas dos Santos ${ }^{\mathrm{a}}$, Kely de Picoli Souza ${ }^{\mathrm{a}, *}$ \\ ${ }^{a}$ Research group on Biotechnology and Bioprospecting Applied to Metabolism, Federal University of Grande Dourados, Rodovia Dourados Itahum, Km 12, 79804-970 \\ Dourados, MS, Brazil \\ ${ }^{\mathrm{b}}$ Agricultural Sciences, Federal University of Grande Dourados, Rodovia Dourados-Itahum, Km 12, Brazil \\ ${ }^{\mathrm{c}}$ Laboratory of Natural Products and Mass Spectrometry, Federal University of Mato Grosso do Sul, Cidade Universitária, 79070-900 Campo Grande, MS, Brazil \\ ${ }^{\mathrm{d}}$ Polytechnic Institute of Bragança, Agricultural College of Bragança, Campus Santa Apolónia, 5301-855 Bragança, Portugal
}

\section{A R T I C L E I N F O}

\section{Keywords:}

Brazilian peppertree

Safety

Phenolic compounds

Oxidative stress

Glycemic control

Diabetes

\begin{abstract}
A B S T R A C T
Schinus terebinthifolius Raddi, commonly known as Brazilian peppertree, is a plant species widely used in Brazilian traditional medicine for various purposes. The objective of this study was to assess the microbiological quality, safety, chemical profile as well as antioxidant and antidiabetic potentials of different parts of $S$. terebinthifolius. Microbiological analysis of the methanolic extracts of the roots (MESR), stem bark (MESB) and leaves (MESL) of $S$. terebinthifolius showed no microbial growth. The concentrations of phenolic compounds, phenolic acids and flavonoids were determined by spectrophotometry. The phenolic compounds of the MESL were identified by liquid chromatography coupled to a diode array detector and mass spectrometer (LC-DADMS). The antioxidant activities of the extracts were analyzed by 2,2-diphenyl-1-(2,4,6-trinitrophenyl)hydrazyl radical (DPPH•), 2,2'-azino-bis(3-ethylbenzthiazoline-6-sulfonic acid) radical (ABTS $\cdot^{+}$), fluorescence recovery after photobleaching (FRAP), reducing power, $\beta$-carotene bleaching and malondialdehyde (MDA) assays in human erythrocytes. The antidiabetic properties of the extracts were demonstrated in vitro by their inhibition of the $\alpha$-glucosidase enzyme and their anti-glycation activity via fructose and glyoxal. After showing no acute toxicity in vivo, MESL was able to lower postprandial glycemia after glucose overload in normoglycemic mice as well as the water and feed intake, liver weight, glycemia and serum levels of glycated hemoglobin, aspartate transaminase (AST) and alanine transaminase (ALT) in diabetic mice. Overall, S. terebinthifolius extracts showed microbiological safety along with antioxidant and antidiabetic activities, likely mediated by its chemical constituents, such as gallic acid, gallotannins and glycosylated flavonols.
\end{abstract}

\section{Introduction}

Schinus terebinthifolius Raddi, belonging to the Anacardiaceae family, is a medicinal plant native to Brazil, commonly known as aroeira or Brazilian peppertree. Previous studies have shown that $S$. terebinthifolius contains phenolic compounds with different biological activities, as described below. In traditional medicine, this plant is used to treat skin wounds and ulcers, tumors, diarrhea, arthritis as well as urinary and respiratory tract infections (Brandão et al., 2006). Various pharmacological activities have been described for this plant, including antimicrobial (Silva et al., 2017a), antiulcerogenic (Carlini et al., 2010), anticancer (Silva et al., 2017b), antihistamine (Nunes-Neto et al.,
2017), antihypertensive (Glória et al., 2017), antihyperalgesic (Piccinelli et al., 2015), wound healing (Estevão et al., 2017), anti-inflammatory (Silva et al., 2017b) and antioxidant (Rocha et al., 2017) activities in different models.

The increasing use of medicinal plants and/or natural products highlights the need for studies on their efficacy and safety. Among the main factors affecting these characteristics of natural products, their microbiological quality stands out because the presence and quantity of some species of microorganisms in the raw material may directly affect the biological activity of the final product (Ratajczak et al., 2015). The microbiological analysis of medicinal plants and/or non-sterile pharmaceutical products aims to identify and quantify the microbial content

\footnotetext{
* Corresponding author.

E-mail address: kelypicoli@gmail.com (K. de Picoli Souza).
} 
for ensuring the quality and safety of these products for human health (Ratajczak et al., 2015).

Diabetes mellitus is among the diseases currently considered to be a global epidemic, projected to grow among the world population and for which new therapeutic alternatives are constantly sought (Wild et al., 2004; Kharroubi and Darwish, 2015). It is a multifactorial disease characterized by the development of metabolic disorders initially involving the elevation of glycemia in response to poor insulin secretion (type 1 diabetes) or cellular resistance to this hormone (type 2 diabetes) (Kharroubi and Darwish, 2015).

Prolonged exposure to hyperglycemia is directly related to increased levels of free radicals, which trigger or aggravate oxidative stress. In combination, these changes lead to structural and functional abnormalities of the endothelium and other tissues, thus contributing to the development of cardiovascular diseases and other comorbidities in diabetics (Node and Inoue, 2009; Singh et al., 2014; Kharroubi and Darwish, 2015). Diabetic complications are aggravated by factors such as postprandial hyperglycemia and the formation of advanced glycation end products (AGEs) (Node and Inoue, 2009; Singh et al., 2014). Thus, medicinal plants with antioxidant and antihyperglycemic properties have become alternatives in the treatment of diabetes.

In this context, the objectives of this study were to determine the quality and safety; identify the phytochemical constituents; and assess the in vitro as well as in vivo antioxidant and antidiabetic properties of different parts of $S$. terebinthifolius.

\section{Material and methods}

\subsection{Plant material and extract preparation}

The roots, stem bark and leaves of Schinus terebinthifolius Raddi were collected after authorization from the SISBIO (Sistema de Autorização e Informação em Biodiversidade; permit number 45365-1). The plant material was collected in Dourados, Mato Grosso do Sul, Brazil, at geographic coordinates $22^{\circ} 11^{\prime} 43.7568^{\prime \prime} \mathrm{S}$ and $54^{\circ} 56^{\prime} 8.0916^{\prime \prime} \mathrm{W}$. A voucher specimen was deposited in the herbarium of the Federal University of Grande Dourados, UFGD, Brazil (DDMS number 4889). The plant materials were dried in an air circulation oven at $30^{\circ} \mathrm{C} \pm 5^{\circ} \mathrm{C}$ days, pulverized in a knife mill and then maintained under intensive maceration in methanol P.A (99.8\%). The filtrate was concentrated under vacuum on a rotary evaporator at $45{ }^{\circ} \mathrm{C}$ and then lyophilized. The yields of the methanolic extracts were approximately $2 \%$ for the roots (MESR), $7 \%$ for the stem bark (MESB) and 13\% for the leaves (MESL) of S. terebinthifolius.

\subsection{Microbiological analysis}

To assess the microorganisms, $5 \mathrm{~g}$ of powder or $1 \mathrm{~g}$ of extract was aseptically weighed and homogenized with 45 or $9 \mathrm{~mL}$ of $0.5 \%$ sterile peptone solution, respectively. Serial dilutions (1:10) of the sample were prepared using the homogenate in the same sterile diluent. Two independent assays were performed in duplicate, as described below.

\subsubsection{Total mesophilic and psychrophilic microorganisms}

Total mesophilic and psychrophilic microorganisms were quantified according to NP-3788 (2002). Sample dilutions were incorporated $(1 \mathrm{~mL})$ into or plated $(0.1 \mathrm{~mL})$ in plate count agar (PCA) media in Petri dishes. Colonies were counted after incubation in the Petri dishes at $30{ }^{\circ} \mathrm{C}$ for $72 \mathrm{~h}$ and at $15^{\circ} \mathrm{C}$ for 5 days. The results were expressed as colony forming units ( $\mathrm{CFU} / \mathrm{g}$ ).

\subsubsection{Molds and yeasts}

Molds and yeasts were counted in DG18 growth media. Sample dilutions $(0.1 \mathrm{~mL})$ were plated and incubated at $25^{\circ} \mathrm{C}$ for 5 days according to ISO-21527-2 (2008). The microbial counts were expressed as $\mathrm{CFU} / \mathrm{g}$.

\subsubsection{Sulfite-reducing Clostridium sp. spores}

Sulfite-reducing Clostridium sp. spores were quantified according to ISO-15213 (2003). For this purpose, sample dilutions were heated to $80^{\circ} \mathrm{C}$ for $10 \mathrm{~min}$. Subsequently, $1 \mathrm{~mL}$ sample dilutions were added to tubes containing iron sulfite agar. Then, another layer of agar was added. After the media solidified, the tubes were incubated at $37^{\circ} \mathrm{C}$ for 5 days. The formation of black colonies in test tubes was considered a positive result. The results were expressed as $\mathrm{CFU} / \mathrm{g}$.

\subsubsection{Salmonella $s p$}

Salmonella sp. was detected using the immunodiffusion 1-2 test, as described by the AOAC (1989). The results were obtained after preenriching the sample in sterile buffered peptone water (1:10) incubated at $37{ }^{\circ} \mathrm{C}$ for $24 \mathrm{~h}$. The results were visually interpreted by monitoring the development of an immunoband.

\subsubsection{Escherichia coli}

Escherichia coli was quantified using the SimPlate ${ }^{\circledR}$ Total Plate Count BioControl kit according to the AOAC (2005). The culture medium supplied was rehydrated in $9 \mathrm{~mL}$ of distilled water, and the sample dilutions $(1 \mathrm{~mL})$ were inoculated according to the manufacturer's instructions. The content was poured onto 84-well plates. The plates were incubated at $37^{\circ} \mathrm{C}$ for $24 \mathrm{~h}$. E. coli was quantified by counting the number of wells in which fluorescence was observed after exposure to ultraviolet light at $365 \mathrm{~nm}$. E. coli populations were defined based on the number of positive wells, correlating the results with the SimPlate conversion table and expressing them as $\mathrm{CFU} / \mathrm{g}$.

\subsubsection{Staphylococcus aureus}

To identify $0(0.1 \mathrm{~mL})$ were plated in Baird-Parker agar with egg yolk tellurito emulsion, as described in NP-4400-1 (2002), for $48 \mathrm{~h}$ at $37^{\circ} \mathrm{C}$. The results were expressed as $\mathrm{CFU} / \mathrm{g}$.

\subsubsection{Bacillus cereus}

Bacillus cereus was counted according to ISO-7932 (2004) using mannitol-egg yolk-polymyxin B agar (MYP). Sample dilutions $(0.1 \mathrm{~mL})$ were plated and incubated at $30^{\circ} \mathrm{C}$ for $24 \mathrm{~h}$. Typical Bacillus cereus colonies (with a dry and rough red-purple surface with a white precipitate) were counted, and the results were expressed as $\mathrm{CFU} / \mathrm{g}$.

\subsection{Concentrations of phytochemical constituents}

\subsection{1. $\beta$-Carotene and lycopene}

$\beta$-Carotene and lycopene were determined according to the method of Barros et al. (2007). The extract $(150 \mathrm{mg}$ ) was vigorously shaken with $10 \mathrm{~mL}$ of an acetone-hexane mixture (4:6) for $1 \mathrm{~min}$ and filtered through Whatman No. 4 filter paper. The absorbance of the filtrate was measured at 453, 505 and $663 \mathrm{~nm}$. The contents of $\beta$-carotene and lycopene were calculated according to the following equations: $\beta$-carotene $=0.216 \times \mathrm{A}_{663}-0.304 \times \mathrm{A}_{505}+0.452 \times \mathrm{A}_{453} ;$ and lycopene $=-0.0458 \times \mathrm{A}_{663}+0.372 \times \mathrm{A}_{505}-0.0806 \times \mathrm{A}_{453}$. The assays were carried out in triplicate. The results were expressed as the mean value \pm standard deviation as $\mathrm{mg}$ of carotenoid/g of extract.

\subsubsection{Ascorbic acid}

The ascorbic acid was determined according to the method of Barros et al. (2007). The extract $(100 \mathrm{mg})$ was extracted with $10 \mathrm{~mL}$ of $1 \%$ metaphosphoric acid for $45 \mathrm{~min}$ at room temperature and filtered through Whatman No. 4 filter paper. The filtrate $(1 \mathrm{~mL})$ was mixed with $9 \mathrm{~mL}$ of 2,6-dichlorophenolindophenol, and the absorbance was measured within $30 \mathrm{~min}$ at $515 \mathrm{~nm}$. The content of ascorbic acid was calculated on the basis of the calibration curve of ascorbic acid $(0.020-0.12 \mathrm{mg} / \mathrm{mL})$. The assays were carried out in triplicate and expressed as $\mathrm{mg}$ of ascorbic acid/g of extract. 


\subsubsection{Phenolic compounds}

The phenolic compounds were determined according to the method of Pinela et al. (2011). The extract concentrated at $0.625 \mathrm{mg} / \mathrm{mL}$ $(250 \mu \mathrm{L})$ was mixed with $0.1 \% \mathrm{HCl}$ or $2 \% \mathrm{HCl}(4550 \mu \mathrm{L})$ in $95 \%$ ethanol $(250 \mu \mathrm{L})$. After $15 \mathrm{~min}$, the absorbance was measured at 280,320 and $360 \mathrm{~nm}$. The absorbance at $280 \mathrm{~nm}$ was used to estimate the total phenolic content, while $A_{320 n m}$ was used to determine the phenolic acids and $A_{360 n m}$ was used to determine the flavonoids. Gallic acid was used to calculate the standard curve $(50-500 \mu \mathrm{g} / \mathrm{mL})$, and the results were expressed as $\mathrm{mg}$ of gallic acid equivalents (GAE)/g of extract. Caffeic acid was used to calculate the standard curve $(50-500 \mu \mathrm{g} / \mathrm{mL})$, and the results were expressed as mg of caffeic acid equivalents (CAE)/ $\mathrm{g}$ of extract. Quercetin was used to calculate the standard curve $(30-300 \mu \mathrm{g} / \mathrm{mL})$, and the results were expressed as $\mathrm{mg}$ of quercetin equivalents $(\mathrm{QE}) / \mathrm{g}$ of extract. The assays were carried out in triplicate.

\subsubsection{Identification of the constituents by LC-DAD-MS}

The MESL was analyzed by an ultra-fast liquid chromatograph (Prominence, Shimadzu) coupled to a diode array detector (DAD) and mass spectrometer (MicrOTOF-Q III, Bruker Daltonics, Billerica, MA, USA). A Kinetex C18 column $(2.6 \mu \mathrm{m}, 150 \times 2.1 \mathrm{~mm}$, Phenomenex $)$ was used with an injection volume, flow rate and oven temperature of $4 \mu \mathrm{L}, 0.3 \mathrm{~mL} / \mathrm{min}$ and $50{ }^{\circ} \mathrm{C}$, respectively. Acetonitrile (solvent B) and water (solvent A), both containing $0.1 \%$ formic acid, were applied as the mobile phase using the following gradient elution profile: $0-8 \mathrm{~min}$ at $3 \% \mathrm{~B}, 8-30 \mathrm{~min}$ at $8-25 \% \mathrm{~B}, 30-60 \mathrm{~min}$ at $25-80 \% \mathrm{~B}$ and $60-63 \mathrm{~min}$ at $80 \%$ B. For the mass spectrometry, nitrogen was used as the nebulizer gas (4 bar), dry gas $(9 \mathrm{~L} / \mathrm{min}$ ) and collisional gas, and the capillary voltage was $2.5 \mathrm{kV}$. The extract was analyzed at a concentration of $1 \mathrm{mg} / \mathrm{mL}$ in the negative and positive ion modes.

\subsection{Antioxidant activity}

\subsection{1. $D P P H \cdot$ assay}

The 2,2-diphenyl-1-picrylhydrazyl radical (DPPH•) scavenging activity was evaluated according to the method described by Campos et al. (2014). For this experiment, $200 \mu \mathrm{L}$ of the extract was mixed with $1800 \mu \mathrm{L}$ of $0.11 \mathrm{mM} \mathrm{DPPH}$ - solution in $80 \%$ ethanol. The final concentrations of the extract ranged from 0.1 to $1000 \mu \mathrm{g} / \mathrm{mL}$. The mixture was incubated at room temperature in the dark for $30 \mathrm{~min}$. The absorbance was measured at $517 \mathrm{~nm}$. Ascorbic acid and butylated hydroxytoluene (BHT) were used as reference antioxidants. As a control, $200 \mu \mathrm{L}$ of the solvent ( $80 \%$ ethanol) was incubated with $1800 \mu \mathrm{L}$ of the $\mathrm{DPPH}$ - solution. Three independent experiments were performed in triplicate. The percent inhibition was calculated from the control using the following equation: capture activity of DPPH $(\%)=\left(1-\mathrm{Abs}_{\text {sample }} / \mathrm{Abs}_{\text {control }}\right) \times 100$. The concentrations of the extracts resulting in $50 \%$ inhibition $\left(\mathrm{IC}_{50}\right)$ were determined.

\subsubsection{ABTS $^{+}{ }^{+}$assay}

The 2,2'-azino-bis(3-ethylbenzothiazoline-6-sulphonic acid) radical (ABTS ${ }^{+}$) scavenging activity was evaluated according to the method described by Campos et al. (2015). For this experiment, the ABTS ${ }^{+}$ was prepared from a mixture of $5 \mathrm{~mL}$ of ABTS $(7 \mathrm{mM})$ and $88 \mu \mathrm{L}$ of potassium persulfate $(140 \mathrm{mM})$, which was incubated for $12-16 \mathrm{~h}$ at room temperature in the dark. After this period, the ABTS.$^{+}$solution was diluted in absolute ethanol until an absorbance of $0.70 \pm 0.05$ was obtained at $734 \mathrm{~nm}$. Then, $20 \mu \mathrm{L}$ of the extract was added to $1980 \mu \mathrm{L}$ of the ABTS $\cdot^{+}$. The final concentrations of the extract ranged from 0.1 to $200 \mu \mathrm{g} / \mathrm{mL}$. The mixture was incubated at room temperature in the dark for $6 \mathrm{~min}$. The absorbance was evaluated at $734 \mathrm{~nm}$. Ascorbic acid and BHT were used as positive controls. As a control, $20 \mu \mathrm{L}$ of the solvent (80\% ethanol) was incubated with $1980 \mu \mathrm{L}$ of $\mathrm{ABTS} \cdot{ }^{+}$. Three independent experiments were performed in triplicate. The percentage of ABTS.${ }^{+}$inhibition was calculated according to the following equation: inhibition of $\mathrm{ABTS} \cdot{ }^{+}(\%)=\left(\left(\mathrm{Abs}_{\text {control }}-\mathrm{Abs}_{\text {sample }}\right) / \mathrm{Abs}_{\text {control }}\right) \times 100$.
The $\mathrm{IC}_{50}$ values were determined.

\subsubsection{FRAP assay}

The ferric reducing antioxidant power (FRAP) assay was evaluated according to the method described by Pulido et al. (2000). For this experiment, $100 \mu \mathrm{L}$ of extract $(1-1000 \mu \mathrm{g} / \mathrm{mL})$ was mixed with $3 \mathrm{~mL}$ of FRAP reagent and $300 \mu \mathrm{L}$ of distilled water. The FRAP reagent contained $10 \mathrm{~mL}$ of $10 \mathrm{mmol} / \mathrm{L} \mathrm{2,4,6-tri(2-pyridyl)-s-triazine} \mathrm{(TPTZ)} \mathrm{solu-}$ tion in $40 \mathrm{mmol} / \mathrm{L} \mathrm{HCl}, 10 \mathrm{~mL}$ of $20 \mathrm{mmol} / \mathrm{L} \mathrm{FeCl}_{3} \cdot 6 \mathrm{H}_{2} \mathrm{O}$ and $100 \mathrm{~mL}$ of $0.3 \mathrm{~mol} / \mathrm{L}$ acetate buffer $(\mathrm{pH}=3.6)$. The mixture was incubated at room temperature in the dark for $20 \mathrm{~min}$. The absorbance was measured at $595 \mathrm{~nm}$. Ascorbic acid was used as the reference antioxidant. As a control, $100 \mu \mathrm{L}$ of the solvent (80\% ethanol) was incubated with $3 \mathrm{~mL}$ of FRAP reagent and $300 \mu \mathrm{L}$ of distilled water. Three independent experiments were performed in triplicate. The half maximal effective concentration $\left(\mathrm{EC}_{50}\right)$ value was determined using the corresponding regression equation.

\subsubsection{Reducing power assay}

The reducing power was evaluated according to the method described by Berker et al. (2007). For this experiment, $1 \mathrm{~mL}$ of extract $(1-1000 \mu \mathrm{g} / \mathrm{mL})$ was combined with $2.5 \mathrm{~mL}$ of $0.2 \mathrm{M}$ phosphate buffer $(\mathrm{pH}=6.6)$ and $2.5 \mathrm{~mL}$ of $\mathrm{K}_{3} \mathrm{Fe}(\mathrm{CN})_{6}$ solution $(1 \%)$; the mixture was incubated at $50{ }^{\circ} \mathrm{C}$ in a water bath for $20 \mathrm{~min}$. The incubated mixture was let cool to room temperature, and $2.5 \mathrm{~mL}$ of 2,4,6-trichloroanisole (TCA, 10\%) was added. The solution was thoroughly mixed, an aliquot of $2.5 \mathrm{~mL}$ was withdrawn, and $2.5 \mathrm{~mL}$ of water followed by $0.5 \mathrm{~mL}$ of $\mathrm{FeCl}_{3} \cdot 6 \mathrm{H}_{2} \mathrm{O}$ solution $(0.1 \%)$ was added so that the final volume was $5.5 \mathrm{~mL}$. The absorbance was measured at $700 \mathrm{~nm}$ after $2 \mathrm{~min}$. Ascorbic acid was used as the reference antioxidant. As a control, $1 \mathrm{~mL}$ of the solvent ( $80 \%$ ethanol) was combined with $2.5 \mathrm{~mL}$ of $0.2 \mathrm{M}$ phosphate buffer $(\mathrm{pH}=6.6)$ and $2.5 \mathrm{~mL}$ of $\mathrm{K}_{3} \mathrm{Fe}(\mathrm{CN})_{6}$ solution $(1 \%)$; the mixture was incubated at $50{ }^{\circ} \mathrm{C}$ in a water bath for $20 \mathrm{~min}$. The incubated mixture was cooled to room temperature, and $2.5 \mathrm{~mL}$ of TCA (10\%) was added. The solution was thoroughly mixed, an aliquot of $2.5 \mathrm{~mL}$ was withdrawn, and $2.5 \mathrm{~mL}$ of water followed by $0.5 \mathrm{~mL}$ of $\mathrm{FeCl}_{3} \cdot 6 \mathrm{H}_{2} \mathrm{O}$ solution $(0.1 \%)$ were added so that the final volume was $5.5 \mathrm{~mL}$. Three independent experiments were performed in triplicate. The $\mathrm{EC}_{50}$ value was determined using the corresponding regression equation.

\subsection{5. $\beta$-Carotene bleaching assay}

$\beta$-Carotene bleaching inhibition was evaluated according to the method described by Taga et al. (1984). For this experiment, $2 \mathrm{mg}$ of $\beta$ carotene was dissolved in $10 \mathrm{~mL}$ of chloroform. The absorbance was tested after adding $0.2 \mathrm{~mL}$ of the solution to $5 \mathrm{~mL}$ of chloroform and then reading the absorbance of this solution at $470 \mathrm{~nm}$. A reading between 0.6 and 0.9 indicated a workable concentration of $\beta$-carotene. One milliliter of $\beta$-carotene chloroform solution was added with a pipette to a boiling flask that contained $20 \mathrm{mg}$ of linoleic acid and $200 \mathrm{mg}$ of Tween 40 . Chloroform was removed using a rotary evaporator at $40^{\circ} \mathrm{C}$, and $50 \mathrm{~mL}$ of oxygenated distilled water was slowly added to the flask with vigorous agitation to form an emulsion. Five milliliters of the emulsion was added to $0.2 \mathrm{~mL}$ of the extract in spectrophotometer tubes. A blank consisting of $2 \mathrm{mg}$ of linoleic acid, $20 \mathrm{mg}$ of Tween 40 and $5 \mathrm{~mL}$ of oxygenated water was used to bring the spectrophotometer to zero. Tubes were shaken, and absorbance measurements made at $470 \mathrm{~nm}$ immediately after the addition of the emulsion to the extract as well as again after $60 \mathrm{~min}$. The tubes were placed in an agitating water bath at $50{ }^{\circ} \mathrm{C}$. The absorbance was measured at $470 \mathrm{~nm}$. Butylated hydroxyanisol (BHA) was used as reference antioxidant. As a control, $200 \mu \mathrm{L}$ of the solvent ( $80 \%$ ethanol) was incubated with $5 \mathrm{~mL}$ of the emulsion. Three independent experiments were performed in triplicate. The percent inhibition was calculated from the control using the following equation: $\beta$-carotene bleaching inhibition $(\%)=\left(1-\mathrm{Abs}_{\text {sample }} / \mathrm{Abs}_{\text {control }}\right) \times 100$. The $\mathrm{IC}_{50}$ values were determined. 


\subsubsection{Dosage of malondialdehyde (MDA) assay}

The antioxidant assay for the model of human erythrocytes was evaluated according to the method described by Rocha et al. (2017). Human erythrocyte assays were performed after receiving approval from the Research Ethics Committee (Comitê de Ética em Pesquisa, CEP) of the Federal University of Grande Dourados (Universidade Federal da Grande Dourados, UFGD), Brazil (CEP process number 1.739.987). Peripheral blood from healthy donors was collected and placed in tubes containing sodium citrate. The tubes were then centrifuged at $2000 \times g$ for $5 \mathrm{~min}$, and the blood plasma as well as leukocyte layer were discarded. The erythrocytes were washed three times with $0.9 \%$ sodium chloride $(\mathrm{NaCl})$ solution, and then, a $10 \%$ erythrocyte suspension in $0.9 \% \mathrm{NaCl}$ solution was prepared for the assay.

The erythrocytes were pre-incubated at $37{ }^{\circ} \mathrm{C}$ for $30 \mathrm{~min}$ with different concentrations of the extract $(50-250 \mu \mathrm{g} / \mathrm{mL})$. Ascorbic acid was used as a positive control. Then, 2,2'-azobis(2-amidinopropane) dihydrochloride (AAPH) solution ( $50 \mathrm{mM}$ ) was added, and the samples were incubated at $37^{\circ} \mathrm{C}$ for $180 \mathrm{~min}$ with periodic homogenization. After this time, the samples were centrifuged at $2000 \times g$ for $5 \mathrm{~min}$, and $0.5 \mathrm{~mL}$ of the supernatant was mixed with $1 \mathrm{~mL}$ of $10 \mathrm{nmol}$ thiobarbituric acid (TBA) dissolved in $75 \mathrm{mM}$ potassium phosphate monobasic buffer at a $\mathrm{pH}$ of 2.5. As a standard control, $0.5 \mathrm{~mL}$ of MDA solution $(20 \mu \mathrm{M})$ was incubated with $1 \mathrm{~mL}$ of TBA. Samples were maintained at $96^{\circ} \mathrm{C}$ for $45 \mathrm{~min}$. After cooling the solution, $4 \mathrm{~mL}$ of $\mathrm{n}$-butyl alcohol was added, followed by centrifugation at $2000 \times g$ for $15 \mathrm{~min}$. The supernatants from the samples were analyzed at $532 \mathrm{~nm}$. Two independent experiments were performed in duplicate. The MDA levels of the samples were expressed in $\mathrm{nmol} / \mathrm{mL}$ and were obtained by the following formula: $\mathrm{MDA}(\mathrm{nmol} / \mathrm{mL})=\mathrm{ABS}_{\text {sample }} \times\left(20 \times 220.32 \mathrm{ABS}_{\text {standardMDA }}\right)$.

\subsection{Antidiabetic properties}

\subsubsection{Alpha-glucosidase assay}

The $\alpha$-glucosidase assay was performed according to the method described by Kazeem et al. (2013) using $\alpha$-glucosidase from Saccharomyces cerevisiae. The substrate solution $p$-nitrophenyl glucopyranoside (pNPG) was prepared in $20 \mathrm{mM}$ phosphate buffer at a $\mathrm{pH}$ of 6.9. For this experiment, $10 \mu \mathrm{L}$ of $\alpha$-glucosidase $(1.0 \mathrm{U} / \mathrm{mL})$ was pre-incubated with $5 \mu \mathrm{L}$ of the different concentrations of the extract $(1-100 \mu \mathrm{g} / \mathrm{mL})$ for $10 \mathrm{~min}$. Then, $5 \mu \mathrm{L}$ of $3.0 \mathrm{mM}$ pNPG as a substrate dissolved in $20 \mathrm{mM}$ phosphate buffer $(\mathrm{pH}=6.9)$ was then added to start the reaction. The reaction mixture was incubated at $37^{\circ} \mathrm{C}$ for $20 \mathrm{~min}$ and stopped by adding $200 \mu \mathrm{L}$ of $0.1 \mathrm{M} \mathrm{Na}_{2} \mathrm{CO}_{3}$. The $\alpha$-glucosidase activity was determined by measuring the yellow-colored paranitrophenol released from pNPG at $405 \mathrm{~nm}$. A control was prepared using the same procedure but replacing the extract with distilled water. Two independent experiments were performed in triplicate. The results were expressed as a percentage of the blank control. The percentage inhibition is calculated as $\%$ Inhibition $=\left[\left(\mathrm{Abs}_{\text {control }}-\mathrm{Abs}_{\text {extract }}\right) / \mathrm{Abs}_{\text {control }}\right] \times 100$. The $\mathrm{IC}_{50}$ values were determined.

\subsubsection{Anti-glycation assay}

The anti-glycation activity was evaluated according to the method described by Kiho et al. (2004). For this experiment, a solution of $0.1 \mathrm{mM}$ fructose, $30 \mathrm{mM}$ glyoxal and $8 \mathrm{mg} / \mathrm{mL}$ BSA was prepared in phosphate buffer $(0.2 \mathrm{M}, \mathrm{pH}=7.4$, containing $3 \mathrm{mM}$ sodium azide as an antimicrobial agent). Briefly, the $300 \mu \mathrm{L}$ of reaction mixture was composed of BSA $(135 \mu \mathrm{L})$, fructose or glyoxal $(135 \mu \mathrm{L})$, and extract $(30 \mu \mathrm{L})$. After this, the samples were incubated at $37^{\circ} \mathrm{C}$ for $48 \mathrm{~h}$ or $72 \mathrm{~h}$ (under sterile conditions). Then, each sample was examined for the development of fluorescence $\left(\lambda_{\mathrm{ex}}=330 \mathrm{~nm}\right.$ and $\left.\lambda_{\mathrm{em}}=420 \mathrm{~nm}\right)$, against blank on a microtiter plate reader. Quercetin was used as the standard. A control was prepared using the same procedure but replacing the extract with distilled water. Three independent experiments were performed in triplicate. The percent inhibition of each extract was calculated by using the following formula: \% inhibition $=\left(1-\right.$ fluorescence $_{\text {sample }} /$ fluorescence $\left._{\text {control }}\right) \times 100$.

The $\mathrm{IC}_{50}$ values were determined.

\subsection{In vivo studies}

The experimental procedures with mice followed the standards of the CONCEA (Conselho Nacional de Controle de Experimentação Animal) and were approved by the CEUA/UFGD (Comissão de Ética para Uso de Animais/Universidade Federal da Grande Dourados; process number 37/2015). C57Bl/6 mice, 20-30 g and 16-24 weeks of age, were obtained from the UFGD Central Animal Facility, Mato Grosso do Sul (MS), Brazil. The mice were housed in microisolators (5 mice per microisolator) and kept under standard conditions ( $12 \mathrm{~h}$ light and $12 \mathrm{~h}$ dark, $22 \pm 2{ }^{\circ} \mathrm{C}$ ), with access to water and feed ad libitum. Before starting the experiment, the mice were acclimated to the laboratory conditions. The dose administered for in vivo assays was selected based on the acute toxicity study. The dose chosen was one tenth of the dose considered to be safe.

\subsubsection{Acute toxicity}

The acute toxicity test was performed based on the protocols of the Organization for Economic Cooperation and Development (OECD) Guideline 425 . On the first day, one C57Bl/6 mouse, after an $8 \mathrm{~h}$ fasting period, received the dose of $2000 \mathrm{mg} / \mathrm{kg}$ MESL by gavage. Subsequently, four other mice were subjected to $8 \mathrm{~h}$ of fasting and to a single dose of $2000 \mathrm{mg} / \mathrm{kg}$ MESL. The same procedure was subsequently repeated in another group of mice using the dose of $5000 \mathrm{mg} / \mathrm{kg}$ MESL to define the lethal dose for $50 \%$ of the mice $\left(\mathrm{LD}_{50}\right)$. The mice were periodically observed during the first $24 \mathrm{~h}$ and then once daily for $14 \mathrm{~d}$, with the body mass as well as water and food intake recorded. At the end of the observation period, all mice were euthanized. The organs (heart, lungs, liver and kidneys) were removed, weighed and macroscopically analyzed.

\subsubsection{Glucose tolerance test}

The glucose tolerance test (GTT) was performed according to the method described by Lanjhiyana et al. (2011). For this purpose, adult male $\mathrm{C} 57 \mathrm{Bl} / 6$ mice were used. The mice fasted for $12 \mathrm{~h}$ and were divided into the following four groups of five mice each: (I) Control: water by gavage; (II) Glib: $10 \mathrm{mg} / \mathrm{kg}$ glibenclamide by gavage; (III) Met: $100 \mathrm{mg} / \mathrm{kg}$ metformin by gavage; and (IV) MESL: $200 \mathrm{mg} / \mathrm{kg}$ methanolic extract of the leaves of $S$. terebinthifolius by gavage. A glucose solution $(2 \mathrm{~g} / \mathrm{kg})$ was administered by gavage to all mice. Blood samples were collected from the caudal vein at time 0 (immediately before glucose administration) and at 30, 60, 90, 120 and $180 \mathrm{~min}$ after glucose administration. Blood glucose levels were determined using the AccuChek $^{\circledR}$ active blood glucose meter.

\subsubsection{Induction of diabetes and experimental procedures}

Diabetes was induced in C57Bl/6 mice fasted for $12 \mathrm{~h}$ by a single intraperitoneal injection of a $180 \mathrm{mg} / \mathrm{kg}$ alloxan monohydrate solution. The alloxan monohydrate solution was prepared with $0.9 \% \mathrm{NaCl}$. After $72 \mathrm{~h}$, the serum glucose levels were determined using an AccuChek ${ }^{\circledast}$ active blood glucose meter. Mice with fasting glycemia higher than $200 \mathrm{mg} / \mathrm{dL}$ were considered diabetic.

The mice were divided into the following four groups of five animals: (I) ND-Control: normoglycemic mice treated with water; (II) DControl: diabetic mice treated with water; (III) D-Met: diabetic mice treated with $100 \mathrm{mg} / \mathrm{kg}$ metformin; and (IV) D-MESL: diabetic mice treated with $200 \mathrm{mg} / \mathrm{kg}$ methanolic extract of leaves of $S$. terebinthifolius. The treatments were administered by gavage for $28 \mathrm{~d}$ once daily. After this period, the mice were euthanized, and the blood was collected to assess biochemical and hematological parameters. The organs (heart, liver and kidneys) were removed and weighed to calculate the relative mass ( $\mathrm{g}$ of organ per $100 \mathrm{~g}$ of body weight). 
Table 1

Microbiological evaluations (CFU/g) of the powders and the methanolic extracts of roots, stem bark and leaves from Schinus terebinthifolius Raddi.

\begin{tabular}{|c|c|c|c|c|c|c|}
\hline & \multicolumn{3}{|l|}{ Powder } & \multicolumn{3}{|l|}{ Extract } \\
\hline & root & stem bark & leaves & root & stem bark & leaves \\
\hline Mesophilic microorganisms & $1.90 \times 10^{-3} \pm 0.001$ & $1.43 \times 10^{0} \pm 0.11$ & $5.17 \times 10^{-1} \pm 0.01$ & absent & absent & absent \\
\hline Psychrophyle microorganisms & $4.70 \times 10^{\circ} \pm 1.54$ & $4.73 \times 10^{1} \pm 7.70$ & absent & absent & absent & absent \\
\hline Molds and yeasts & $1.93 \times 10^{1} \pm 1.85$ & $4.95 \times 10^{1} \pm 7.70$ & absent & absent & absent & absent \\
\hline Clostridium sulfite reducer & absent & absent & absent & absent & absent & absent \\
\hline Salmonella sp. & absent & absent & absent & absent & absent & absent \\
\hline Escherichia coli & absent & absent & absent & absent & absent & absent \\
\hline Staphylococcus aureus & absent & absent & absent & absent & absent & absent \\
\hline Bacillus cereus & $1.87 \times 10^{1} \pm 7.21$ & absent & absent & absent & absent & absent \\
\hline
\end{tabular}

The results are expressed as the mean \pm SEM.

\subsection{Statistical analysis}

The data are expressed as the mean \pm standard error of the mean (SEM). Analysis of variance (ANOVA) with the Student Newman Keuls post-test was used for analysis and comparison between the experimental groups. The area under the curve (AUC) was used for the GTT. All statistical tests were performed using the software GraphPad Prism, version 5.0. Data were considered significant when $P<0.05$.

\section{Results}

\subsection{Microbiological quality}

Table 1 presents the microbiological evaluation of the powders and MESR, MESB and MESL of $S$. terebinthifolius. The growth of mesophilic microorganisms was observed in the powders of roots, stem bark and leaves of $S$. terebinthifolius. Colonies of psychrophilic microorganisms, molds and yeasts grew in the powders of roots and stem bark. No growth of pathogenic microorganisms was observed, except in root powder, where Bacillus cereus colonies grew. However, no microbial growth occurred in the MESR, MESB and MESL of $S$. terebinthifolius.

\subsection{Chemical constituents}

Table 2 presents the contents of lipophilic and hydrophilic compounds of the MESR, MESB and MESL. The hydrophilic compounds stood out in all extracts, particularly phenolic compounds, which were the main components. The MESB and MESL had the highest concentrations of phenolic acids and flavonoids.

\subsection{Antioxidant activity}

The antioxidant activities of the MESR, MESB and MESL were observed in the DPPH $\cdot$, ABTS $\cdot{ }^{+}$, FRAP, reducing power, $\beta$-carotene bleaching (Table 3 ) and MDA assays in human erythrocytes (Fig. 1).

Regarding the controls used, the $\mathrm{IC}_{50} \mathrm{DPPH} \cdot$ and ABTS ${ }^{+}$concentrations of the extracts were similar to those of ascorbic acid and lower than those of BHT (Table 3). The $\mathrm{EC}_{50}$ values of the MESL in the FRAP and reducing power assays were lower than those of the MESR and MESB as well as approximately twice as high as those of ascorbic acid (Table 3).

In the $\beta$-carotene bleaching assay (Table 3), the MESL had a lower $\mathrm{IC}_{50}$ than the other extracts and (approximately 18 times) a higher $\mathrm{IC}_{50}$ than the antioxidant BHA. The $\mathrm{IC}_{50}$ of ascorbic acid was not detected in this assay.

In human erythrocytes, the extracts reduced the oxidative stress induced by the oxidant agent AAPH, as shown by the lower levels of MDA generated (Fig. 1). At the concentrations tested (50 to $125 \mu \mathrm{g}$ / $\mathrm{mL}$ ), the MESL promoted lower levels of MDA than the other extracts and the control, ascorbic acid (Fig. 1).

\subsection{In vitro antidiabetic properties}

The antidiabetic properties of the MESR, MESB and MESL were determined in vitro by the inhibition of the activity of the digestive enzyme $\alpha$-glucosidase and by the anti-glycation effect via fructose as well as glyoxal (Table 4).

$S$. terebinthifolius extracts inhibited the activity of the enzyme $\alpha$ glucosidase, and the MESL showed a higher activity than the other extracts, with an $\mathrm{IC}_{50}$ approximately twice as low as that of the other extracts (Table 4). The MESL showed higher anti-glycation activity than the other extracts, and the control quercetin had an $\mathrm{IC}_{50}$ (approximately 4 times) higher than fructose and similar to that of glyoxal (Table 4).

\subsection{Chemical profile of the MESL}

The chemical constituents were identified by their UV spectra, accurate mass and fragment ions compared to published data in the literature, and some metabolites were confirmed by the injection of authentic standards.

The identified constituents were $O$-glycosylated flavonols 4-7, 9-10, 12-14, 16-17, and 19-20; gallotannins 3, 8, 15, and 18; and gallic acid 1 along with its derivatives 2 and 11 (Fig. 2, Table 5). The main compounds observed in the chromatogram $(\lambda=270-330 \mathrm{~nm})$ were $4-O$ -

Table 2

Lipophilic and hydrophilic compounds of the methanolic extracts of roots (MESR), stem bark (MESB) and leaves (MESL) from Schinus terebinthifolius Raddi.

\begin{tabular}{|c|c|c|c|}
\hline Compounds & MESR & MESB & MESL \\
\hline \multicolumn{4}{|l|}{ Lipophilic } \\
\hline$\beta$-Carotene (mg/g extract) & $0.054 \pm 0.006^{\mathrm{a}}$ & $0.313 \pm 0.027^{\mathrm{b}}$ & $1.455 \pm 0.009^{c}$ \\
\hline Lycopene (mg/g extract) & $0.029 \pm 0.002^{\mathrm{a}}$ & $0.049 \pm 0.008^{\mathrm{b}}$ & $0.013 \pm 0.002^{\mathrm{a}}$ \\
\hline \multicolumn{4}{|l|}{ Hydrophilic } \\
\hline Ascorbic acid (mg/g extract) & $0.115 \pm 0.002^{\mathrm{a}}$ & $0.123 \pm 0.002^{\mathrm{a}}$ & $0.070 \pm 0.003^{\mathrm{b}}$ \\
\hline Phenolics (mg GAE/g extract) & $300.42 \pm 9.30^{\mathrm{a}}$ & $274.94 \pm 8.09^{\mathrm{a}}$ & $446.48 \pm 28.93^{b}$ \\
\hline Phenolic acids (mg CAE/g extract) & $24.49 \pm 1.80^{\mathrm{a}}$ & $49.12 \pm 1.30^{\mathrm{b}}$ & $52.95 \pm 4.23^{\mathrm{b}}$ \\
\hline Flavonoids (mg QE/g extract) & $21.16 \pm 2.65^{\mathrm{a}}$ & $55.72 \pm 1.56^{\mathrm{b}}$ & $57.78 \pm 3.79^{\mathrm{b}}$ \\
\hline
\end{tabular}

The results are expressed as the mean \pm SEM. 
Table 3

Antioxidant activities of the methanolic extract of root (MESR), stem bark (MESB) and leaves (MESL) from Schinus terebinthifolius Raddi.

\begin{tabular}{|c|c|c|c|c|c|}
\hline \multirow[t]{2}{*}{ Sample } & DPPH & $\mathrm{ABTS}^{+}{ }^{+}$ & FRAP & Reducing power & $\beta$-carotene bleaching \\
\hline & $\mathrm{IC}_{50}(\mu \mathrm{g} / \mathrm{mL})$ & & $\mathrm{EC}_{50}(\mu \mathrm{g} / \mathrm{mL})$ & & $\mathrm{IC}_{50}(\mu \mathrm{g} / \mathrm{mL})$ \\
\hline Ascorbic acid & $3.06 \pm 0.16$ & $2.31 \pm 0.05$ & $33.58 \pm 0.80$ & $42.97 \pm 0.70$ & ND \\
\hline Lipophilic antioxidant & $37.45 \pm 3.09$ & $20.87 \pm 1.82$ & - & - & $3.80 \pm 0.10$ \\
\hline MESR & $6.31 \pm 0.06$ & $3.25 \pm 0.22$ & $85.11 \pm 4.27$ & $133.52 \pm 1.11$ & $176.56 \pm 21.30$ \\
\hline MESB & $4.50 \pm 0.11$ & $4.45 \pm 0.49$ & $116.33 \pm 3.53$ & $169.76 \pm 1.90$ & $220.37 \pm 35.99$ \\
\hline MESL & $4.17 \pm 0.69$ & $3.83 \pm 0.36$ & $68.78 \pm 2.01$ & $95.30 \pm 3.64$ & $67.06 \pm 3.78$ \\
\hline
\end{tabular}

Lipophilic antioxidant: BHT for DPPH $\cdot$ and ABTS $\cdot{ }^{+}$; BHA for the $\beta$-carotene bleaching assay. ND: not detected. -: unrealized. The results are expressed as the mean \pm SEM.

methyl gallic acid 2 and penta-O-galloyl hexoside 15 (Fig. 2).

The peaks 1,2 and 11 showed a $\lambda_{\max } \approx 280 \mathrm{~nm}$, and gallic acid (1) was confirmed by a standard. Compound 2 exhibited intense ions at $m$ / $z 185.0451[\mathrm{M}+\mathrm{H}]^{+}$and $183.0304[\mathrm{M}-\mathrm{H}]^{-}$, confirming the molecular formula $\mathrm{C}_{8} \mathrm{H}_{8} \mathrm{O}_{5}$ and an additional methyl on the gallic acid. The fragment ion at $m / z 153.0186\left(\mathrm{C}_{7} \mathrm{H}_{5} \mathrm{O}_{4}{ }^{+}\right.$, error $\left.=2.4 \mathrm{ppm}\right)$ indicated the loss of a methanol molecule ( $32 u$ ), which is a diagnostic ion for a methyl group at C-4 (Liao et al., 2013) because the losses of radical methyl and, subsequently, $\mathrm{CO}_{2}$ molecules suggest a methyl substituent at C-3 or C-7 (carboxyl) (Kumar et al., 2015; Ersan et al., 2016). For compound 11 , the ion $m / z \quad 335.0412 \quad[\mathrm{M}-\mathrm{H}]^{-} \quad\left(\mathrm{C}_{15} \mathrm{H}_{11} \mathrm{O}_{9}{ }^{-}\right.$, error $=2.8 \mathrm{ppm}$ ) yielded the fragment ion at $m / z 183$ by the loss of a galloyl unit, which is relative to a methylated galloyl, as reported by Ersan et al. (2016). Thus, compounds 1, 2 and 11 were identified as gallic acid, 4-O-methyl gallic acid and methyl digallate, respectively.

The substances $3,8,15$ and 18 showed absorption bands with a $\lambda_{\text {max }}$ similar to gallic acid. In addition, they revealed consecutive losses of galloyl units (152 $u$ ) and/or losses of a galloyl unit and subsequently a water molecule $(170 \mathrm{u})$. They also showed the typical fragment ion at $\mathrm{m} / \mathrm{z} 169$ [gallic acid-H] $^{-}$and the absence of an ion at $\mathrm{m} / \mathrm{z} 301$, which confirmed the identification of gallotannins (Ersan et al., 2016; Muccilli et al., 2017). For example, compound 15 exhibited an intense ion at $\mathrm{m} / \mathrm{z}$ 939.1102 [M-H] ${ }^{-}$(compatible with $\mathrm{C}_{41} \mathrm{H}_{31} \mathrm{O}_{26}{ }^{-}$) and yielded fragment ions by the losses of galloyl units such as $m / z 787$ [M-H-galloyl] ${ }^{-}, 769$ $\left[\mathrm{M}-\mathrm{H} \text {-galloyl- } \mathrm{H}_{2} \mathrm{O}\right]^{-}, 617\left[\mathrm{M}-\mathrm{H}-2 \times \text { galloyl }-\mathrm{H}_{2} \mathrm{O}\right]^{-}, 599[\mathrm{M}-\mathrm{H}-2 \times$ galloyl-2 $\left.\times \mathrm{H}_{2} \mathrm{O}\right]^{-}, 447$ [M-H-3 $\times$ galloyl- $\left.2 \times \mathrm{H}_{2} \mathrm{O}\right]^{-}$, and 277 [M-H$4 \times$ galloyl- $\left.3 \times \mathrm{H}_{2} \mathrm{O}\right]^{-}$; thus, they confirmed the identification of penta$O$-galloyl hexoside, a compound already described for $S$. terebinthifolius (Hayashi et al., 1989). Additionally, the substances 3, 8 and 18 were identified as tri-O-galloyl hexoside, tetra-O-galloyl hexoside and hexa$O$-galloyl hexoside, respectively. All data agreed with the published data for these compounds (Abu-Reidah et al., 2015; Kumar et al., 2015; Ersan et al., 2016; Muccilli et al., 2017).

Compounds 4-7, 9-10, 12-14, 16-17 and 19-20 revealed UV

\section{Table 4}

$\alpha$-Glucosidase inhibition and anti-glycation activity by the methanolic extracts of the roots (MESR), stem bark (MESB) and leaves (MESL) from Schinus terebinthifolius Raddi.

\begin{tabular}{lcll}
\hline Sample & $\alpha$-Glucosidase & \multicolumn{2}{l}{ Anti-glycation } \\
\cline { 3 - 4 } & & Fructose & Glyoxal \\
\hline & $\mathrm{IC}_{50}(\mu \mathrm{g} / \mathrm{mL})$ & $\mathrm{IC}_{50}(\mu \mathrm{g} / \mathrm{mL})$ & \\
\hline Quercetin & - & $0.32 \pm 0.01$ & $35.12 \pm 0.27$ \\
MESR & $31.16 \pm 0.17$ & $3.16 \pm 0.01$ & $116.18 \pm 2.23$ \\
MESB & $33.01 \pm 1.65$ & $1.54 \pm 0.03$ & $98.43 \pm 0.48$ \\
MESL & $16.13 \pm 0.49$ & $1.29 \pm 0.01$ & $32.40 \pm 0.84$ \\
\hline
\end{tabular}

The results are expressed as the mean \pm SEM.

spectra similar to flavonol $\left(\lambda_{\max } \approx 265\right.$ and $350 \mathrm{~nm}$ ) (Ersan et al., 2016). The substances $4-7,9$ and 19 yielded a main fragment ion at $\mathrm{m} / \mathrm{z}$ 316 , while compounds 10,12 , and 16 as well as 14,17 , and 20 yielded fragment ions at $\mathrm{m} / \mathrm{z} 284$ and 300 in negative ion mode, which are compatible with the aglycones myricetin $\left(\mathrm{C}_{15} \mathrm{H}_{8} \mathrm{O}_{8}{ }^{-}\right)$, quercetin $\left(\mathrm{C}_{15} \mathrm{H}_{8} \mathrm{O}_{7}{ }^{-} \cdot\right)$ and kaempferol $\left(\mathrm{C}_{15} \mathrm{H}_{8} \mathrm{O}_{6}{ }^{-} \cdot\right)$. The losses of 132,146 and $162 u$ confirmed the sugars pentosyl, deoxyhexosyl and hexosyl, respectively. All of the fragment ions were similar to data reported in the literature (March et al., 2006; Liao et al., 2013; Ersan et al., 2016).

\subsection{Acute toxicity}

Table 6 presents the anthropometric parameters of mice treated with the MESL in the acute toxicity test. No mortality was observed during the experimental period after administering doses of 2000 and $5000 \mathrm{mg} / \mathrm{kg}$ MESL. The mice treated with $2000 \mathrm{mg} / \mathrm{kg}$ MESL showed no changes in the anthropometric parameters (Table 6). However, the mice treated with $5000 \mathrm{mg} / \mathrm{kg}$ MESL showed decreased body mass, increased water and feed intake and a slight decrease in kidney weight

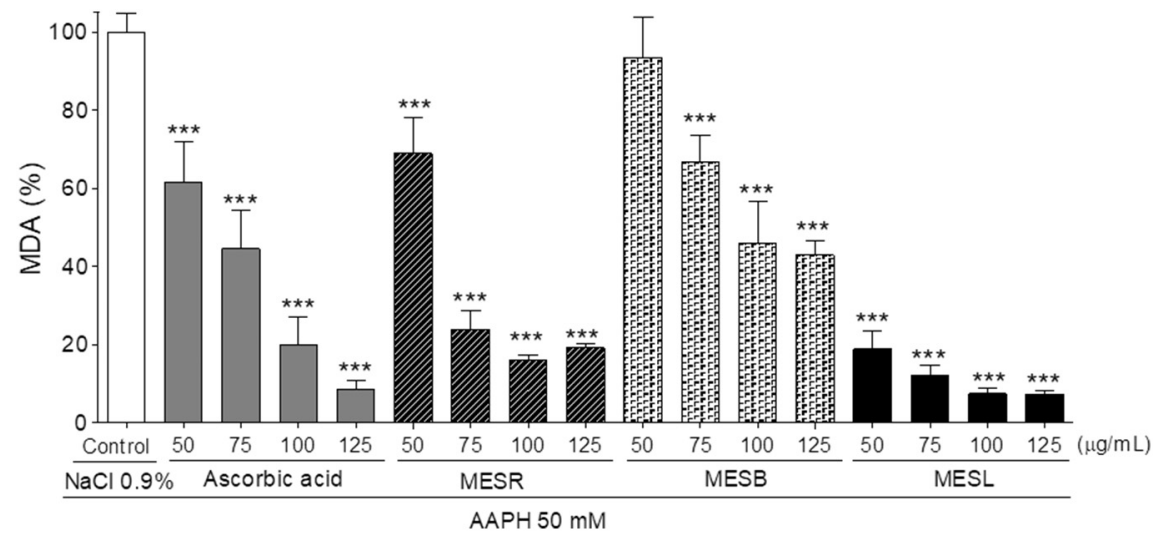

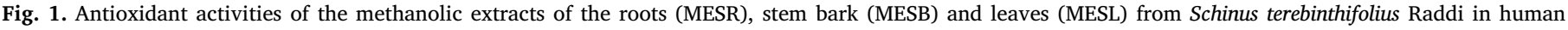

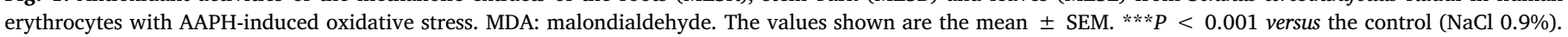




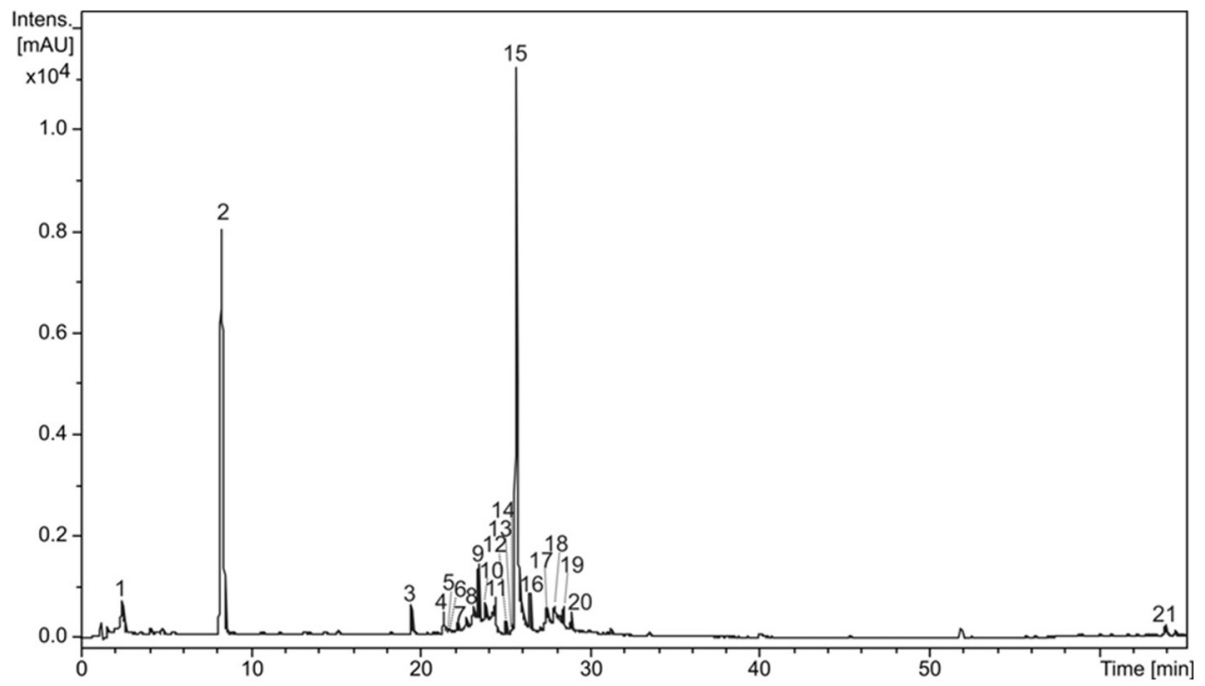

Fig. 2. Chromatographic profile at $270-330 \mathrm{~nm}$ of the methanolic extract of Schinus terebinthifolius Raddi leaves (MESL).

when compared with the other groups. Thus, considering the data together, the $\mathrm{LD}_{50}$ of the MESL was estimated as higher than $5000 \mathrm{mg} / \mathrm{kg}$, and the in vivo assays proceeded with a dose of $200 \mathrm{mg} / \mathrm{kg}$, that is, 10 times lower than the dose considered safe in this study.

\subsection{In vivo antidiabetic properties}

\subsubsection{Oral glucose tolerance test}

Fig. 3 shows the effects of the MESL on the glycemia of normoglycemic mice after oral glucose overload. The MESL reduced the glycemic peak at 30 min by $35 \pm 5 \%$ (Fig. 3A) as well as the postprandial glycemia by $24 \pm 6 \%$, as assessed by the AUC up to $180 \mathrm{~min}$ (Fig. 3B) when compared with the control group. Furthermore, the effects of the MESL on the glycemia of normoglycemic mice were similar to those induced by glibenclamide and weaker than those of metformin.

\subsubsection{In vivo antidiabetic activity}

Table 7 presents the anthropometric and biochemical parameters of normoglycemic (ND-Control) and diabetic C57Bl/6 mice treated with water (D-Control), metformin (D-Met) and the MESL (D-MESL). The evolution of the glycemic parameters of all the experimental groups are represented in Table S1.

Diabetic mice (D-Control) showed higher water and feed intake, glycemia, glycated hemoglobin, AST and ALT liver enzymes and liver weight than the ND-Control group (Table 7). Diabetic mice treated with the MESL (D-MESL) showed decreased water intake, and the other anthropometric and biochemical parameters were normal (Table 7). In all experimental groups, the organs (liver, kidneys, heart and pancreas)

Table 5

Identification of the constituents from the MESL of Schinus terebinthifolius by LC-DAD-MS/MS.

\begin{tabular}{|c|c|c|c|c|c|c|c|c|}
\hline \multirow[t]{2}{*}{ Peak } & \multirow[t]{2}{*}{$\mathrm{RT}(\min )$} & \multirow[t]{2}{*}{ Compound } & \multirow[t]{2}{*}{$\mathrm{UV}(\mathrm{nm})$} & \multirow[t]{2}{*}{ FM } & \multicolumn{2}{|l|}{ Negative mode $m / z$} & \multicolumn{2}{|l|}{ Positive mode $m / z$} \\
\hline & & & & & MS $[\mathrm{M}-\mathrm{H}]^{-}\left(\mathrm{ppm}^{\mathrm{er}}\right)$ & MS/MS & $\begin{array}{l}\text { MS }[\mathrm{M}+\mathrm{H}]^{+} \\
\left(\mathrm{ppm}^{\mathrm{er}}\right)\end{array}$ & MS/MS \\
\hline 1 & 2.4 & Gallic acid* & 270 & $\mathrm{C}_{7} \mathrm{H}_{6} \mathrm{O}_{5}$ & $169.0146(2.1)$ & - & $171.0295(4.0)$ & - \\
\hline 2 & 8.2 & 4-O-methyl gallic acid & 271 & $\mathrm{C}_{8} \mathrm{H}_{8} \mathrm{O}_{5}$ & $183.0304(2.8)$ & - & $185.0451(3.6)$ & 153 \\
\hline 3 & 19.5 & Tri-O-galloyl hexoside & 278 & $\mathrm{C}_{27} \mathrm{H}_{24} \mathrm{O}_{18}$ & $635.0873(2.7)$ & $465,313,169$ & $659.0883^{\mathrm{Na}}(4.3)$ & 153 \\
\hline 4 & 21.4 & Myricetin $O$-hexoside & 265,365 & $\mathrm{C}_{21} \mathrm{H}_{20} \mathrm{O}_{13}$ & $479.0819(2.6)$ & 316 & 481.0993 (3.3) & 319 \\
\hline 5 & 21.6 & $\begin{array}{l}\text { Myricetin } O \text {-hexosyl- } \\
\text { deoxyhexoside }\end{array}$ & 265,355 & $\mathrm{C}_{27} \mathrm{H}_{30} \mathrm{O}_{17}$ & $625.1396(2.3)$ & 479,316 & $627.1564(1.3)$ & 481,319 \\
\hline 6 & 21.8 & $\begin{array}{l}\text { Myricetin } O \text {-hexosyl- } \\
\text { deoxyhexoside }\end{array}$ & 265,355 & $\mathrm{C}_{27} \mathrm{H}_{30} \mathrm{O}_{17}$ & $625.1416(1.0)$ & 479,316 & $627.1585(4.6)$ & 481,319 \\
\hline 7 & 22.3 & Myricetin $O$-pentoside & 265,353 & $\mathrm{C}_{20} \mathrm{H}_{18} \mathrm{O}_{12}$ & $449.0721(1.0)$ & 316 & 451.0888 (3.7) & $319,273,245,167$ \\
\hline 8 & 23.2 & Tetra-O-galloyl hexoside & 278 & $\mathrm{C}_{34} \mathrm{H}_{28} \mathrm{O}_{22}$ & $787.1000(0.1)$ & $635,617,465,169$ & $811.0966^{\mathrm{Na}}(0.2)$ & - \\
\hline 9 & 23.5 & Myricetin $O$-deoxyhexoside & 265,350 & $\mathrm{C}_{21} \mathrm{H}_{20} \mathrm{O}_{12}$ & $463.0882(1.3)$ & 316,271 & $465.1048(4.3)$ & $319,245,217,153$ \\
\hline 10 & 23.8 & Quercetin $O$-hexoside & 265,353 & $\mathrm{C}_{21} \mathrm{H}_{20} \mathrm{O}_{12}$ & $463.0881(0.2)$ & 300 & $465.1044(3.6)$ & 303 \\
\hline 11 & 24.4 & Methyl digallate & 275 & $\mathrm{C}_{15} \mathrm{H}_{12} \mathrm{O}_{9}$ & $335.0412(1.1)$ & 183 & $337.0568(4.2)$ & 153 \\
\hline 12 & 25.1 & Quercetin $O$-pentoside & 263,355 & $\mathrm{C}_{20} \mathrm{H}_{18} \mathrm{O}_{11}$ & $433.0775(0.4)$ & 300,271 & $435.0911(2.5)$ & 303 \\
\hline 13 & 25.5 & Quercetin $O$-pentoside & 263,355 & $\mathrm{C}_{20} \mathrm{H}_{18} \mathrm{O}_{11}$ & $433.0772(0.9)$ & 300,271 & $435.0938(3.7)$ & 303 \\
\hline 14 & 25.6 & Kaempferol $O$-hexoside & 263,350 & $\mathrm{C}_{21} \mathrm{H}_{20} \mathrm{O}_{11}$ & $447.0950(3.9)$ & 284 & $449.1086(1.8)$ & 287 \\
\hline 15 & 25.7 & Penta-O-galloyl hexoside & 279 & $\mathrm{C}_{41} \mathrm{H}_{32} \mathrm{O}_{26}$ & $939.1102(0.8)$ & $\begin{array}{c}787,769,617,599,447,277 \\
169,125\end{array}$ & $963.1107^{\mathrm{Na}}(3.4)$ & $\begin{array}{c}793,641,471,301, \\
153\end{array}$ \\
\hline 16 & 26.5 & Quercetin $O$-deoxyhexoside & 260,350 & $\mathrm{C}_{21} \mathrm{H}_{20} \mathrm{O}_{11}$ & $447.0943(2.2)$ & $300,271,255$ & 449.1070 (1.9) & 303 \\
\hline 17 & 27.1 & Kaempferol $O$-pentoside & 263,350 & $\mathrm{C}_{20} \mathrm{H}_{34} \mathrm{O}_{9}$ & $417.2125(1.3)$ & 284 & 419.0991 (4.5) & 287 \\
\hline 18 & 27.9 & Hexa-O-galloyl hexoside & 280 & $\mathrm{C}_{48} \mathrm{H}_{36} \mathrm{O}_{30}$ & $1091.1212(0.6)$ & $921,769,617,393$ & $1115.1175^{\mathrm{Na}}(0.7)$ & - \\
\hline 19 & 28.5 & $\begin{array}{c}\text { Myricetin } O \text {-galloyl } O \text { - } \\
\text { deoxyhexoside }\end{array}$ & $\begin{array}{l}267,280 \\
350\end{array}$ & $\mathrm{C}_{28} \mathrm{H}_{24} \mathrm{O}_{16}$ & $615.1003(1.9)$ & 317 & $617.1145(1.2)$ & - \\
\hline 20 & 28.9 & Kaempferol $O$-deoxyhexoside & 263,350 & $\mathrm{C}_{21} \mathrm{H}_{20} \mathrm{O}_{10}$ & $431.0989(1.1)$ & 284 & $433.1121(2.0)$ & 287 \\
\hline 21 & 64.0 & Unknown & 300 & $\mathrm{C}_{24} \mathrm{H}_{36} \mathrm{O}_{3}$ & $371.2581(2.8)$ & 327 & $373.2747(2.7)$ & 355 \\
\hline
\end{tabular}

$\left(\mathrm{ppm}^{\mathrm{er}}\right)$ : Error in ppm; ${ }^{\mathrm{Na}}:[\mathrm{M}+\mathrm{Na}]^{+}$; *: confirmed by an authentic standard. 
Table 6

Anthropometric parameters of $\mathrm{C} 57 \mathrm{Bl} / 6$ normal mice in the acute toxicity test treated with the methanolic extract of leaves from Schinus terebinthifolius Raddi (MESL).

\begin{tabular}{lccc}
\hline \multirow{2}{*}{$\begin{array}{l}\text { Anthropometric } \\
\text { parameters }\end{array}$} & Control & \multicolumn{2}{l}{ MESL } \\
\cline { 2 - 4 } & & $2000 \mathrm{mg} / \mathrm{kg}$ & $5000 \mathrm{mg} / \mathrm{kg}$ \\
\hline \multirow{2}{*}{$\mathrm{BW}(\%)$} & $-0.31 \pm 1.30^{\mathrm{a}}$ & $-2.78 \pm 1.62^{\mathrm{ab}}$ & $-5.73 \pm 1.11^{\mathrm{b}}$ \\
Water intake (mL/day) & $6.25 \pm 0.45^{\mathrm{a}}$ & $6.02 \pm 0.52^{\mathrm{a}}$ & $12.36 \pm 0.77^{\mathrm{b}}$ \\
Food intake (g/day) & $3.84 \pm 0.21^{\mathrm{a}}$ & $5.14 \pm 0.31^{\mathrm{ab}}$ & $6.30 \pm 0.65^{\mathrm{b}}$ \\
Liver $(\mathrm{g} / 100 \mathrm{~g}$ of BW) & $3.93 \pm 0.10$ & $3.59 \pm 0.09$ & $3.75 \pm 0.14$ \\
Lung $(\mathrm{g} / 100 \mathrm{~g}$ of $\mathrm{BW})$ & $0.60 \pm 0.02$ & $0.68 \pm 0.09$ & $0.62 \pm 0.02$ \\
Kidney (g/100 g of BW) & $1.06 \pm 0.02^{\mathrm{ab}}$ & $1.11 \pm 0.06^{\mathrm{a}}$ & $0.95 \pm 0.02^{\mathrm{b}}$ \\
Heart $(\mathrm{g} / 100 \mathrm{~g}$ of BW) & $0.56 \pm 0.03$ & $0.57 \pm 0.04$ & $0.54 \pm 0.02$ \\
\hline
\end{tabular}

$\Delta$ BW (\%): variation in the \% between the final and initial body weight. The values shown are the mean \pm SEM. $N=5$ mice per group. Different letters indicate statistically significant differences.

were evaluated macroscopically and no presented changes in respect to their color, consistency, size or presence of lesions e tumors. The effects of the MESL on the parameters assessed in diabetic mice were stronger than those triggered by the reference drug metformin at the concentrations tested (Table 7).

\section{Discussion}

Scientific knowledge about the biological activities of medicinal plants may stimulate the development of new therapeutic alternatives. Schinus terebinthifolius Raddi is a medicinal plant commonly used for various purposes, and it is included in the list of medicinal plants indicated by the Brazilian public health system (RENISUS, 2009).

Natural products are subjected to microbiological and toxicological assessments to determine their safety. The presence of microorganisms in plants results from different soil, air and water contaminants. Many of these contaminants in non-sterile pharmaceuticals can alter their therapeutic properties and damage health (Ratajczak et al., 2015). The presence of the pathogenic microorganism Bacillus cereus exclusively in the $S$. terebinthifolius root powder and the absence of microbial growth in the extracts of all plant parts may indicate the microbiological safety of these plant materials, characterizing them as high-quality natural products (Santos et al., 2018). Furthermore, the absence of toxicity signs in the acute toxicity test supports the pharmacological potential of S. terebinthifolius.

Plant extracts have a set of different bioactive constituents, and phenolic compounds were the major constituents hydrophilic of the $S$. terebinthifolius extracts. However, different parts of the same plant may have different composition of phytochemical constituents (Singh et al., 2015). Among the extracts, the MESL had the highest content of phenolic compounds and $\beta$-Carotene (lipophilic compound) as well as the highest efficacy for the biological activities tested. Phenolic compounds are known to act as antioxidants, especially for their ability to donate hydrogen or electrons, thereby inhibiting the action of reactive oxygen species (ROS) and lipid peroxidation reactions (Rice-Evans et al., 1997).

The free radical scavenging observed in this study indicates the potential of these extracts to donate electrons to stabilize radical molecules. This ability is crucial because the excess of free radicals is one of the main factors that causes and worsens pathological conditions such as cancer (Reuter et al., 2010), obesity (Fernandez-Sanchez et al., 2011), cardiovascular diseases (Csányi and Miller, 2014) and diabetes (Giacco and Brownlee, 2010).

The hydroxyl radical $(\mathrm{OH} \cdot)$ is one of the most reactive molecules for which no endogenous defense system is available (Lipinski, 2011). $\mathrm{OH} \cdot$ is formed in Fenton's reaction, in which ferrous iron $\left(\mathrm{Fe}^{2+}\right)$ is oxidized to ferric iron $\left(\mathrm{Fe}^{3+}\right)$ by hydrogen peroxide $\left(\mathrm{H}_{2} \mathrm{O}_{2}\right)$ (Winterbourn, 1995). S. terebinthifolius extracts showed a lower iron reducing power than the ascorbic acid standard, and therefore, they can avoid $\mathrm{OH}$. generation. Some antioxidants with a high iron reducing power may have pro-oxidant characteristics (Chobot and Hadacek, 2011).

In biological systems, membrane lipids are targets of $\mathrm{OH} \cdot$, which is able to oxidize polyunsaturated fatty acids and form lipid hydroperoxides (Ayala et al., 2014). The inhibition of the oxidation of the lipid substrate $\beta$-carotene by $S$. terebinthifolius extracts may indicate the ability to prevent changes in membrane structure and permeability resulting from lipid peroxidation.

Those membrane changes may result from the toxic byproducts of lipid peroxidation, such as MDA (Grotto et al., 2009). In human erythrocytes under induced oxidative stress, $S$. terebinthifolius extracts reduced the MDA levels generated, with the MESL showing the highest effect.

Oxidative stress affects virtually all physiological systems and is associated with the development of various diseases, including diabetes (Giacco and Brownlee, 2010). Increased glycemia also increases free radical production, primarily through protein glycation (Singh et al., 2014). Glycated hemoglobin and fructosamine are examples of Amadori products that form AGEs (Gillery, 2014). The formation of AGEs is closely related to the development of diabetic complications (Node and Inoue, 2009; Singh et al., 2014); therefore, glycemic control is critical to prevent such events (Skyler, 2004). The binding of AGEs to their
A

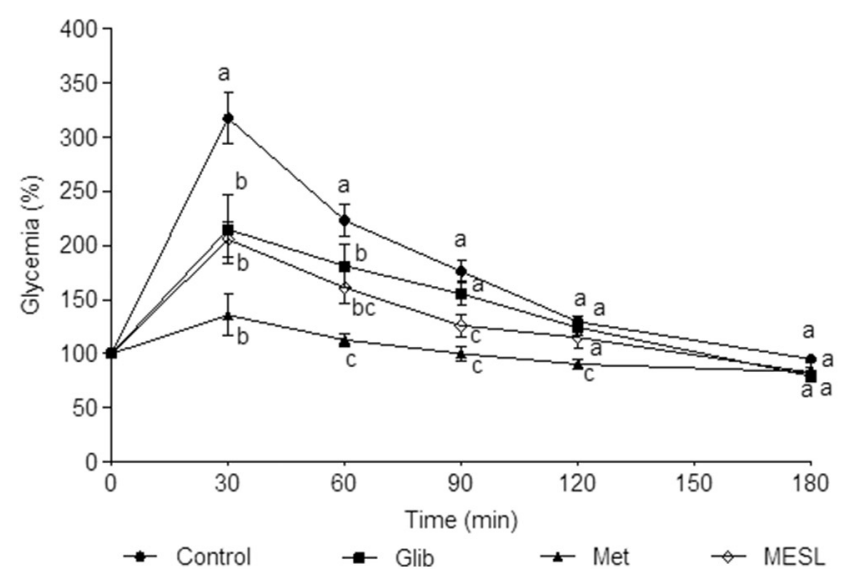

B

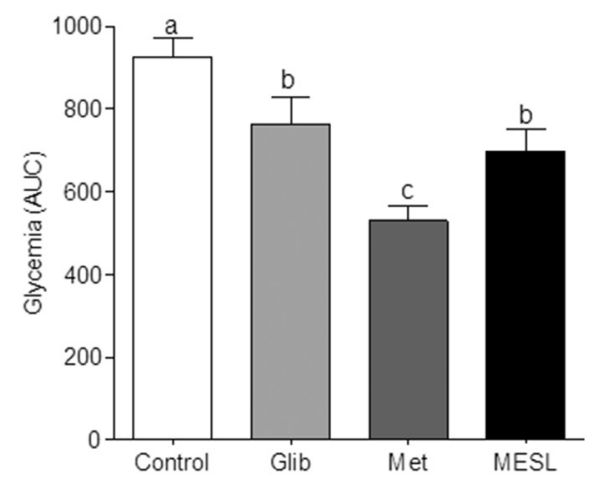

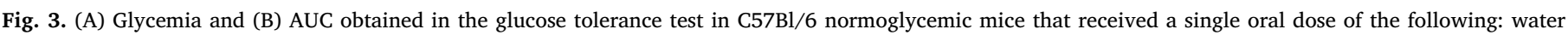

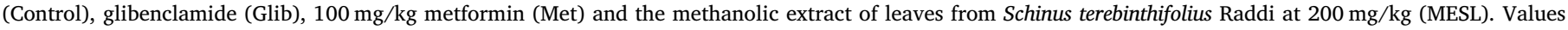
shown are the mean \pm SEM. $N=5$ mice per group. Different letters indicate statistically significant differences. 
Table 7

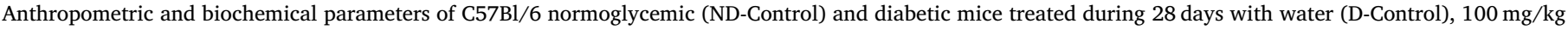
metformin (D-Met) and the methanolic extract of leaves from Schinus terebinthifolius Raddi at $200 \mathrm{mg} / \mathrm{kg}$ (D-MESL).

\begin{tabular}{|c|c|c|c|c|}
\hline \multirow[t]{2}{*}{ Parameters } & \multirow{2}{*}{$\frac{\text { Normal }}{\text { ND-Control }}$} & \multicolumn{3}{|l|}{ Diabetic } \\
\hline & & D-Control & D-Met & D-MESL \\
\hline \multicolumn{5}{|l|}{ Anthropometric } \\
\hline$\Delta \mathrm{BW}(\%)$ & $5.71 \pm 2.43$ & $0.43 \pm 4.21$ & $7.95 \pm 3.12$ & $8.60 \pm 2.05$ \\
\hline Water intake (mL/day) & $7.51 \pm 0.38^{\mathrm{a}}$ & $30.41 \pm 1.49^{b}$ & $23.32 \pm 1.15^{c}$ & $11.23 \pm 0.76^{\mathrm{d}}$ \\
\hline Food intake (g/day) & $4.55 \pm 0.24^{\mathrm{a}}$ & $6.79 \pm 0.47^{\mathrm{b}}$ & $6.51 \pm 0.17^{\mathrm{b}}$ & $4.81 \pm 0.23^{\mathrm{a}}$ \\
\hline Liver $(\mathrm{g} / 100 \mathrm{~g}$ of $\mathrm{BW})$ & $4.14 \pm 0.15^{\mathrm{ac}}$ & $5.21 \pm 0.15^{\mathrm{b}}$ & $4.69 \pm 0.20^{\mathrm{ab}}$ & $4.02 \pm 0.17^{\mathrm{c}}$ \\
\hline Kidney (g/100 g of BW) & $1.08 \pm 0.03$ & $1.48 \pm 0.05$ & $1.12 \pm 0.09$ & $1.03 \pm 0.03$ \\
\hline Heart $(\mathrm{g} / 100 \mathrm{~g}$ of $\mathrm{BW})$ & $0.45 \pm 0.01$ & $0.46 \pm 0.01$ & $0.45 \pm 0.01$ & $0.49 \pm 0.03$ \\
\hline Pancreas (g/100 g of BW) & $0.27 \pm 0.06$ & $0.16 \pm 0.06$ & $0.20 \pm 0.06$ & $0.21 \pm 0.03$ \\
\hline \multicolumn{5}{|l|}{ Biochemical } \\
\hline Glycemia (mg/dL) & $134.40 \pm 6.39^{\mathrm{a}}$ & $481.25 \pm 14.57^{\mathrm{b}}$ & $288.00 \pm 74.69^{c}$ & $160.33 \pm 22.00^{\mathrm{a}}$ \\
\hline HbA1c (\%) & $4.82 \pm 0.02^{\mathrm{a}}$ & $9.13 \pm 0.48^{\mathrm{b}}$ & $6.74 \pm 1.26^{\mathrm{ab}}$ & $6.05 \pm 0.61^{\mathrm{a}}$ \\
\hline Total cholesterol (mg/dL) & $99.74 \pm 6.90$ & $105.55 \pm 7.98$ & $95.44 \pm 6.41$ & $108.73 \pm 1.57$ \\
\hline HDL-cholesterol (mg/dL) & $102.72 \pm 8.41$ & $107.90 \pm 7.68$ & $91.24 \pm 6.35$ & $106.92 \pm 2.17$ \\
\hline Triglyceride (mg/dL) & $50.80 \pm 4.13$ & $48.90 \pm 5.36$ & $56.36 \pm 6.32$ & $66.27 \pm 5.63$ \\
\hline AST (U/L) & $63.54 \pm 6.15^{\mathrm{a}}$ & $163.08 \pm 20.04^{\mathrm{b}}$ & $77.84 \pm 13.06^{\mathrm{a}}$ & $61.23 \pm 7.98^{\mathrm{a}}$ \\
\hline ALT (U/L) & $26.32 \pm 2.58^{\mathrm{a}}$ & $71.98 \pm 15.29^{\mathrm{b}}$ & $35.20 \pm 4.61^{\mathrm{a}}$ & $30.48 \pm 4.01^{\mathrm{a}}$ \\
\hline Urea $(\mathrm{mg} / \mathrm{dL})$ & $106.34 \pm 8.86$ & $143.25 \pm 20.51$ & $112.82 \pm 12.72$ & $105.55 \pm 8.37$ \\
\hline Creatinine (mg/dL) & $0.23 \pm 0.02$ & $0.27 \pm 0.02$ & $0.25 \pm 0.02$ & $0.23 \pm 0.01$ \\
\hline
\end{tabular}

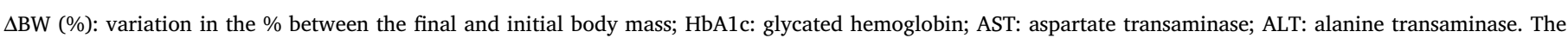
values shown are the mean \pm SEM. $N=5$ mice per group. Different letters indicate statistically significant differences.

receptors (RAGEs) leads to cellular dysfunction, which includes the increased production of inflammatory cytokines, such as interleukin 1 and 6 (IL-1 and IL-6), growth factor I (GF-1) and tumor necrosis factor alpha (TNFa) (Singh et al., 2014). AGEs accumulate in most target organs of diabetes, such as the kidneys and retina (Singh et al., 2014). The anti-glycation activity of the extracts was shown by the decreased glycation via fructose and glyoxal, and the MESL had a higher antiglycation activity than the other extracts. Diabetic animals treated with the MESL showed reduced levels of glycated hemoglobin.

Oxidative stress, hyperglycemia and diabetes control have been related to the action of various natural substances, particularly phenolic compounds (Rice-Evans et al., 1997; Xie and Chen, 2013). Gallic acid and its derivatives, gallotannins and glycosylated flavonols of myricetin, quercetin and kaempferol were identified in the MESL. In other studies, these phenolic compounds have been related to antioxidant action and glycemic control. Gallic acid and its derivatives have been described as oxidative stress reducers (Abdel-Moneim et al., 2017; Karimi-Khouzani et al., 2017; Omobowale et al., 2017). Tannins have antioxidant properties, although they primarily maintain glycemic levels by inhibiting $\alpha$-glucosidase (Lee et al., 2017; Muccilli et al., 2017). Studies indicate the effect of glycosylated quercetin on glycemic reduction by protecting pancreatic cells or improving insulin sensitivity (Yan et al., 2015). Decreased fasting glycemia and the serum levels of glycated hemoglobin have already been observed in vivo after the administration of glycosylated kaempferol (Zang et al., 2015). Other studies observed that glycosylated flavonols are also capable of inhibiting $\alpha$-glycosidase activity (Sun et al., 2014) and glycating proteins in vitro (Kim et al., 2004). In addition to the above effects, the MESL reduced postprandial glycemia in normoglycemic mice after glucose overload, thus indicating their ability to change mechanisms of glycemic control.

The mechanisms currently used to control hyperglycemia include the inhibition of the activity of the digestive enzyme $\alpha$-glucosidase, which regulates the uptake of glucose generated from starch (van de Laar, 2008). Glucosidase inhibitors, such as acarbose, miglitol and voglibose, act as enzymatic $\alpha$-glucosidase antagonists, reducing intestinal glucose uptake and postprandial glycemia, albeit causing side effects such as flatulence, diarrhea and abdominal pain (van de Laar et al., 2005). S. terebinthifolius extracts, especially the MESL, inhibited $\alpha$-glycosidase activity, and the inhibition of this enzyme has been a promising target for the development of antidiabetic drugs (van de Laar,
2008).

The classic symptoms of chronic hyperglycemia, polydipsia and polyphagia, which reflect homeostatic imbalances in diabetes (Fournier, 2000; American Diabetes Association, 2009), were partly or fully reversed with the administration of the MESL to diabetic mice. Feed intake normalization in diabetic mice treated with the MESL correlates positively with the decrease in glucose and glycated hemoglobin levels observed in these animals.

Similarly, hepatomegaly as well as the elevated AST and ALT levels of diabetic mice, likely related to the excessive glycogen accumulation in hepatocytes (Sarkhy et al., 2017), were fully reversed in diabetic mice treated with the MESL, which showed normalization of the liver weight as well as the liver enzymes AST and ALT, similarly to mice treated with metformin.

Overall, the data showed that $S$. terebinthifolius extracts are microbiologically safe and these extracts, particularly the MESL, help control oxidative stress, postprandial hyperglycemia and the main symptoms of diabetes. This action is most likely mediated by their chemical constituents, such as gallic acid, gallotannins and glycosylated flavonols.

\section{Declaration of interest}

The authors report no conflicts of interest. The authors alone are responsible for the content and writing of this article.

Supplementary data to this article can be found online at https:// doi.org/10.1016/j.cbpc.2019.02.007.

\section{Acknowledgements}

This work was supported by grants from Foundation to Support to Fundação de Apoio ao Desenvolvimento do Ensino, Ciência e Tecnologia do Estado de Mato Grosso do Sul (FUNDECT), Coordenação de Aperfeiçoamento de Pessoal de Nível Superior (CAPES), and Conselho Nacional de Desenvolvimento Científico e Tecnológico (CNPq).

\section{References}

Abdel-Moneim, A., Yousef, A.I., Abd El-Twab, S.M., Abdel Reheim, E.S., Ashour, M.B. 2017. Gallic acid and p-coumaric acid attenuate type 2 diabetes-induced neurodegeneration in rats. Metab. Brain Dis. 32, 1279-1286. https://doi.org/10.1007/ 
s11011-017-0039-8

Abu-Reidah, I.M., Ali-Shtayeh, M.S., Jamous, R.M., Arráez-Román, D., Segura-Carretero, A., 2015. HPLC-DAD-ESI-MS/MS screening of bioactive components from Rhus coriaria L. (Sumac) fruits. Food Chem. 166, 179-191. https://doi.org/10.1016/j foodchem.2014.06.011.

American Diabetes Association, 2009. Diagnosis and classification of diabetes mellitus. Diabetes Care 32, 62-67. https://doi.org/10.2337/dc09-S062.

AOAC. Motile Salmonella in All Foods Immunodiffusion 1-2 Teste - Method First Action. Association of Official Analytical Chemists: Arlington, VA, USA, 1989-13.

AOAC. Detection and confirmed quantitation of coliforms and Escherichia coli in foods SimPlate coliform and Escherichia coli color indicator first action. Association of Official Analytical Chemists: Arlington, VA, USA, 2005-03.

Ayala, A., Munoz, M.F., Arguelles, S., 2014. Lipid peroxidation: production, metabolism, and signaling mechanisms of malondialdehyde and 4-hydroxy-2-nonenal. Oxidative Med. Cell. Longev. 2014, 360438. https://doi.org/10.1155/2014/360438.

Barros, L., Ferreira, M.J., Queirós, B., Ferreira, I.C.F.R., Baptista, P., 2007. Total phenols, ascorbic acid, $\beta$-carotene and lycopene in Portuguese wild edible mushrooms and their antioxidant activities. Food Chem. 103, 413-419. https://doi.org/10.1016/j. foodchem.2006.07.038.

Berker, K.I., Güçlï, K., Tor, I., Apak, R., 2007. Comparative evaluation of Fe(III) reducing power-based antioxidant capacity assays in the presence of phenanthroline, bathophenanthroline, tripyridyltriazine (FRAP), and ferricyanide reagents. Talanta. 72, 1157-1165. https://doi.org/10.1016/j.talanta.2007.01.019.

Brandão, M.G.L., Consenza, G.P., Moreira, R.A., Monte-Mor, R.L.M., 2006. Medicinal plants and other botanical products from the Brazilian official pharmacopeia. Rev. Bras 16, 408-420. https://doi.org/10.1590/S0102-695X2006000300020.

Campos, J.F., Santos, U.P., Macorini, L.F., Melo, A.M., Balestieri, J.B., Paredes-Gamero, E.J., Cardoso, C.A., de Picoli Souza, K., Santos, E.L., 2014. Antimicrobial, antioxidant and cytotoxic activities of propolis from Melipona orbignyi (hymenoptera, Apidae). Food Chem. Toxicol. 65, 374-380. https://doi.org/10.1016/j.fct.2014.01.008.

Campos, JF, Santos, UP, Rocha, PS, Damiao, MJ, Balestieri, JB, Cardoso, CA, ParedesGamero, EJ, Estevinho, LM, de Picoli Souza, K, Santos, EL, 2015. Antimicrobial, Antioxidant, Anti-Inflammatory, and Cytotoxic Activities of Propolis from the Stingless Bee Tetragonisca fiebrigi (Jatai). Evidence-Based Complementary and Alternative. 296186, 01-11. doi: https://doi.org/10.1155/2015/296186

Carlini, E.A., Duarte-Almeida, J.M., Rodrigues, E., Tabach, R., 2010. Antiulcer effect of the pepper trees Schinus terebinthifolius Raddi (aroeira-da-praia) and Myracrodruon urundeuva Allemão, Anacardiaceae (aroeira-do-sertão). Braz. J. Pharmacognosy 20 140-146. https://www.researchgate.net/publication/247854122.

Chobot, V., Hadacek, F., 2011. Exploration of pro-oxidant and antioxidant activities of the flavonoid myricetin. Redox Rep. 16, 242-247. https://doi.org/10.1179/ 1351000211 Y.0000000015.

Csányi, G., Miller, F.J., 2014. Oxidative stress in cardiovascular disease. Int. J. Mol. Sci. 15, 6002-6008. https://doi.org/10.3390/ijms15046002.

van de Laar, F.A., 2008. Alpha-glucosidase inhibitors in the early treatment of type 2 diabetes. Vasc. Health Risk Manag. 4, 1189-1195 (PMC2663450).

van de Laar, F.A.V., Lucassen, P.L., Akkermans, R.P., Lisdonk, E.H.V., Rutten, G.E., Weel, C.V., 2005. $\alpha$-Glucosidase inhibitors for patients with type 2 diabetes. Diabetes Care 28, 154-163. https://doi.org/10.2337/diacare.28.1.154.

Ersan, S., Guclu Ustundag, O., Carle, R., Schweiggert, R.M., 2016. Identification of phenolic compounds in red and green pistachio (Pistacia vera L.) hulls (Exo- and Mesocarp) by HPLC-DAD-ESI-(HR)-M(n)S. J. Agric. Food Chem. 64, 5334-5344. https://doi.org/10.1021/acs.jafc.6b01745.

Estevão, L.R.M., Simões, R.S., Cassini-Vieira, P., Canesso, M.C.C., Barcelos, L.D.S., Rachid, M.A., Câmara, C.A.G.D., Evêncio-Neto, J., 2017. Schinus terebinthifolius Raddi (Aroeira) leaves oil attenuates inflammatory responses in cutaneous wound healing in mice 1. Acta Cir. Bras. 32, 726-735. https://doi.org/10.1590/s0102865020170090000005 .

Fernandez-Sanchez, A., Madrigal-Santillan, E., Bautista, M., Esquivel-Soto, J., MoralesGonzalez, A., Esquivel-Chirino, C., Durante-Montiel, I., Sanchez-Rivera, G., ValadezVega, C., Morales-Gonzalez, J.Á., 2011. Inflammation, oxidative stress, and obesity. Int. J. Mol. Sci. 12, 3117-3132. https://doi.org/10.3390/ijms12053117.

Fournier, A., 2000. Diagnosing Diabetes. J. Gen. Intern. Med. 15, 603-604. https://doi. org/10.1046/j.1525-1497.2000.00535.x.

Giacco, F., Brownlee, M., 2010. Oxidative stress and diabetic complications. Circ. Res. 107, 1058-1070. https://doi.org/10.1161/CIRCRESAHA.110.223545.

Gillery, P., 2014. Assays of HbA1c and Amadori products in human biology. Ann. Pharm. Fr. 72, 330-336. https://doi.org/10.1016/j.pharma.2014.04.002.

Glória, L.L., Arantes, M.B.S., Pereira, S.M.F., Vieira, G.S., Martins, C.X., Junior, A.R.C. Antunes, F., Braz-Filho, R., Vieira, I.J.C., Cruz, L.L., Chaves, D.S.A., Freitas, S.P., Barros de Oliveira, D.B., 2017. Phenolic compounds present Schinus terebinthifolius Raddi influence the lowering of blood pressure in rats. Molecules. 22, E1792. https:// doi.org/10.3390/molecules22101792.

Grotto, D., Maria, L.S., Valentini, J., Paniz, C., Schmitt, G., Garcia, S.C., Pomblum, V.J., Rocha, J.B.T., Farina, M., 2009. Importance of the lipid peroxidation biomarkers and methodological aspects FOR malondialdehyde quantification. Quim. Nova 32 169-174. https://doi.org/10.1590/S0100-40422009000100032.

Hayashi, T., Nagayama, K., Arisawa, M., Shimizu, M., Suzuki, S., Yoshizaki, M., Morita N., Ferro, E., Basualdo, I., Berganza, L.H., 1989. Pentagalloylglucose, a xanthine oxidase inhibitor from a Paraguayan crude drug, "Molle-I" (Schinus terebinthifolius). J. Nat. Prod. 52, 210-211. 2723668.

ISO 15213. Microbiology of food and animal feeding stuffs - Horizontal method for the enumeration of sulfite-reducing bacteria growing under anaerobic conditions, 2003-05.

ISO 21527-2. Microbiology of food and animal feeding stuffs - Horizontal method for the enumeration of yeasts and moulds - Part 2: Colony count technique in products with water activity less than or equal to $0.95,2008-07$.

ISO 7932. Microbiology of food and animal feeding stuffs - Horizontal method for the enumeration of presumptive Bacillus cereus - Colony-count technique at $30{ }^{\circ} \mathrm{C}$, 2004-06.

Karimi-Khouzani, O., Heidarian, E., Amini, A.S., 2017. Anti-inflammatory and ameliorative effects of gallic acid on fluoxetine-induced oxidative stress and liver damage in rats. Pharmacol. Rep. 69, 830-835. https://doi.org/10.1016/j.pharep.2017.03. 011.

Kazeem, MI, Adamson, JO, Ogunwande, IA, 2013. Modes of inhibition of alpha-amylase and alpha-glucosidase by aqueous extract of Morinda lucida Benth leaf. Biomed. Res. Int. 527570, 01-06. doi: https://doi.org/10.1155/2013/527570.

Kharroubi, A.T., Darwish, H.M., 2015. Diabetes mellitus: the epidemic of the century. World J. Diabetes 6, 850-867. https://doi.org/10.4239/wjd.v6.i6.850.

Kiho, T., Usui, S., Hirano, K., Aizawa, K., Inakuma, T., 2004. Tomato paste fraction inhibiting the formation of advanced glycation end-products. Biosci. Biotechnol. Biochem. 68, 200-205. https://doi.org/10.1271/bbb.68.200.

Kim, H.Y., Moon, B.H., Lee, H.J., Choi, D.H., 2004. Flavonol glycosides from the leaves of Eucommia ulmoides O. with glycation inhibitory activity. J. Ethnopharmacol. 93, 227-230. https://doi.org/10.1016/j.jep.2004.03.047.

Kumar, S., Chandra, P., Bajpai, V., Singh, A., Srivastava, M., Mishra, D.K., Kumar, B., 2015. Rapid qualitative and quantitative analysis of bioactive compounds from Phyllanthus amarus using LC/MS/MS techniques. Ind. Crop. Prod. 69, 143-152. https://doi.org/10.1016/j.indcrop.2015.02.012.

Lanjhiyana, S, Garabadu, D, Ahirwar, D, Bigoniya, P, Rana, AC, Patra, KC, Lanjhiyana, SK, Karuppai, M, 2011. Antidiabetic activity of methanolic extract of stem bark of Elaeodendron glaucum Pers. in Alloxanized rat model. Advances in Applied Science Research. 2, 47-62. doi: http://www.imedpub.com/articles/antidiabetic-activity-ofmethanolic-extract-of-stem-bark-ofelaeodendron-glaucum-pers-in-alloxanized-ratmodel.pdf

Lee, D.Y., Kim, H.W., Yang, H., Sung, S.H., 2017. Hydrolyzable tannins from the fruits of Terminalia chebula Retz and their $\alpha$-glucosidase inhibitory activities. Phytochemistry. 137, 109-116. https://doi.org/10.1016/j.phytochem.2017.02.006.

Liao, S.G., Zhang, L.J., Sun, F., Wang, Z., He, X., Wang, A.M., Li, Y.J., Huang, Y., Lan, Y.Y., Zhang, B.L., Wang, Y.L., 2013. Identification and characterisation of phenolics in Polygonum capitatum by ultrahigh-performance liquid chromatography with photodiode array detection and tandem mass spectrometry. Phytochem. Anal. 24, 556-568. https://doi.org/10.1002/pca.2432.

Lipinski, B., 2011. Hydroxyl radical and its scavengers in health and disease. Oxidative Med. Cell. Longev. 809696, 01-09. https://doi.org/10.1155/2011/809696.

March, R.E., Lewars, E.G., Stadey, C.J., Miao, X.S., Zhao, X., Metcalfe, C.D., 2006. A comparison of flavonoid glycosides by electrospray tandem mass spectrometry. Int. J. Mass Spectrom. 248, 61-85. https://doi.org/10.1016/j.ijms.2005.09.011.

Muccilli, V., Cardullo, N., Spatafora, C., Cunsolo, V., Tringali, C., 2017. $\alpha$-Glucosidase inhibition and antioxidant activity of an oenological commercial tannin. Extraction, fractionation and analysis by HPLC/ESI-MS/MS and (1) HNMR. Food Chem. 215, 50-60. https://doi.org/10.1016/j.foodchem.2016.07.136.

Node, K., Inoue, T., 2009. Postprandial hyperglycemia as an etiological factor in vascular failure. Cardiovasc. Diabetol. 8, 23. https://doi.org/10.1186/1475-2840-8-23.

NP 3788. Microbiologia Alimentar - Regras gerais para a contagem de microrganismos a $30{ }^{\circ} \mathrm{C}$. Instituto Português da Qualidade (IPQ): Lisboa, Portugal, 2002.

NP 4400-1. Microbiologia Alimentar - Regras gerais para contagem de Estafilococos coagulase positiva - Staphylococcus aureus e outras espécies - Parte 1: Técnica com confirmação de colónias - método corrente. Instituto Português da Qualidade (IPQ): Lisboa, Portugal, 2002.

Nunes-Neto, PA, Peixoto-Sobrinho, TJS, Júnior, EDS, Leopoldina da Silva, JL, Oliveira, ARS, Pupo, AS, Araújo, AV, Costa-Silva, JH, Wanderley, AG, 2017. The effect of Schinus terebinthifolius Raddi (Anacardiaceae) bark extract on histamine-induced paw edema and ileum smooth muscle contraction. Evid. Based Complement. Alternat. Med. 2017, 01-10. doi: https://doi.org/10.1155/2017/1416375.

OECD, 425. Test $\mathrm{N}^{\circ} 425$ - Acute Oral Toxicity - Up-and-Down Procedure. @OECD_Pubs. Omobowale, TO, Oyagbemi, A.A., Ajufo, U.E., Adejumobi, O.A., Ola-Davies, O.E., Adedapo, A.A., Yakubu, M.A., 2017. Ameliorative effect of Gallic acid in doxorubicin induced hepatotoxicity in Wistar rats through antioxidant defense system. J. Diet. Suppl. 15, 183-196. https://doi.org/10.1080/19390211.2017.1335822.

Piccinelli, A.C., Santos, J.A., Konkiewitz, E.C., Oesterreich, S.A., Formagio, A.S., Croda, J., Ziff, E.B., Kassuya, C.A., 2015. Antihyperalgesic and antidepressive actions of (R)$(+)$-limonene, $\alpha$-phellandrene, and essential oil from Schinus terebinthifolius fruits in a neuropathic pain model. Nutr. Neurosci. 18, 217-224. https://doi.org/10.1179/ 1476830514Y.0000000119.

Pinela, J., Barros, L., Carvalho, A.M., Ferreira, I.C.F.R., 2011. Influence of the drying method in the antioxidant potential and chemical composition of four shrubby flowering plants from the tribe Genisteae (Fabaceae). Food Chem. Toxicol. 49, 2983-2989. https://doi.org/10.1016/j.fct.2011.07.054.

Pulido, R., Bravo, L., Saura-Calixto, F., 2000. Antioxidant activity of dietary polyphenols as determined by a modified ferric reducing/antioxidant power assay. J. Agric. Food Chem. 48, 3396-3402. https://doi.org/10.1021/jf9913458.

Ratajczak, M., Kubicka, M.M., Kamińska, D., Sawicka, P., Długaszewska, J., 2015. Microbiological quality of non-sterile pharmaceutical products. Saudi Pharmaceutical J. 23, 303-307. https://doi.org/10.1016/j.jsps.2014.11.015.

RENISUS (2009) Relação Nacional de Plantas Medicinais de Interesse ao SUS http:// portalarquivos2.saude.gov.br/images/pdf/2014/maio/07/renisus.pdf

Reuter, S., Gupta, S.C., Chaturvedi, M.M., Aggarwal, B.B., 2010. Oxidative stress, inflammation, and cancer: how are they linked? Free Radic. Biol. Med. 49, 1603-1616. https://doi.org/10.1016/j.freeradbiomed.2010.09.006.

Rice-Evans, C., Miller, N., Paganga, G., 1997. Antioxidant properties of phenolic compounds. Trends Plant Sci. 2, 152-159. https://doi.org/10.1016/S1360-1385(97) 
01018-2.

Rocha, P.S., Campos, J.F., Nunes-Souza, V., Vieira, M.C., Boleti, A.P.A., Rabelo, L.A. Santos, E.L., de Picoli Souza, K., 2017. Antioxidant and protective effects of Schinus terebinthifolius Raddi against doxorubicin-induced toxicity. Appl. Biochem. Biotechnol. 184, 869-884. https://doi.org/10.1007/s12010-017-2589-y.

Santos, U.P.S., Tolentino, G.S., Morais, J.S., Souza, K.P., Estevinho, M.L.M.F., Santos, E.L., 2018. Physicochemical characterization, microbiological quality and safety, and pharmacological potential of Hancornia speciosa Gomes. Oxidative Med. Cell. Longev. 2018, 2976985. https://doi.org/10.1155/2018/2976985.

Sarkhy, A.A.A., Zaidi, Z.A., Babiker, A.M., 2017. Glycogenic hepatopathy, an underdiagnosed cause of relapsing hepatitis in uncontrolled type 1 diabetes mellitus. Saudi Med. J. 38, 89-92. https://doi.org/10.15537/smj.2017.1.15934.

Silva, J.H.S., Simas, N.K., Alviano, C.S., Alviano, D.S., Ventura, J.A., Lima, E.J., Seabra, S.H., Kuster, R.M., 2017a. Anti-Escherichia coli activity of extracts from Schinus terebinthifolius fruits and leaves. Nat. Prod. Res. 3, 1-4. https://doi.org/10.1080/ 14786419.2017.1344657.

Silva, M.M., Iriguchi, E.K.K., Kassuya, C.A.L., Vieira, M.C., Foglio, M.A., Carvalho, J.E., Ruiz, A.L.T.G., Souza, K.P., Formagio, A.S.N., 2017b. Schinus terebinthifolius: phenolic constituents and in vitro antioxidant, antiproliferative and in vivo anti-inflammatory activities. Rev. Bras 27, 445-452. https://doi.org/10.1016/j.bjp.2016.12.007.

Singh, V.P., Bali, A., Singh, N., Jaggi, A.S., 2014. Advanced glycation end products and diabetic complications. Kor. J. Physiol. Pharmacol. 18, 01-14. https://doi.org/10. 4196/kjpp.2014.18.1.1.

Singh, A., Bajpai, V., Srivastava, M., Arya, K.R., Kumar, B., 2015. Rapid screening and distribution of bioactive compounds in different parts of Berberis petiolaris using direct analysis in real time mass spectrometry. J. Pharm. Anal. 5, 332-335. https:// doi.org/10.1016/j.jpha.2015.05.002

Skyler, J.S., 2004. Effects of glycemic control on diabetes complications and on the prevention of diabetes. Clin. Diab. 22, 162-166. https://doi.org/10.2337/diaclin.22. 4.162

Sun, J., Zhang, F., Yang, M., Zhang, J., Chen, L., Zhan, R., Li, L., Chen, Y., 2014. Isolation of $\alpha$-glucosidase inhibitors including a new flavonol glycoside from Dendrobium devonianum. Nat. Prod. Res. 28, 1900-1905. https://doi.org/10.1080/14786419.2014. 955495.

Taga, M.S., Miller, E.E., Pratt, D.E., 1984. Chia seeds as a source of natural lipid antioxidants. J. Am. Oil Chem. Soc. 61, 928-931. https://link.springer.com/article/10. 1007/BF02542169.

Wild, S., Roglic, G., Green, A., Sicree, R., King, H., 2004. Global prevalence of diabetes: estimates for the year 2000 and projections for 2030. Diabetes Care 27, 1047-1053. 15111519.

Winterbourn, C.C., 1995. Toxicity of iron and hydrogen peroxide: the Fenton reaction. Toxicol. Lett. 82, 969-974. https://doi.org/10.1016/0378-4274(95)03532-X.

Xie, Y., Chen, X., 2013. Structures required of polyphenols for inhibiting advanced glycation end products formation. Curr. Drug Metab. 14, 414-431. https://doi.org/10. 2174/1389200211314040005.

Yan, S.X., Li, X., Sun, C.D., Chen, K.S., 2015. Hypoglycemic and hypolipidemic effects of quercetin and its glycosides. Zhongguo Zhong Yao Za Zhi 40, 4560-4567 (27141664).

Zang, Y., Zhang, L., Igarashi, K., Yu, C., 2015. The anti-obesity and anti-diabetic effects of kaempferol glycosides from unripe soybean leaves in high-fat-diet mice. Food Funct. 6, 834-841. https://doi.org/10.1039/c4fo00844h. 